\title{
THE TRADEMARK FUNCTION OF AUTHORSHIP
}

\author{
GREG LASTOWKA*
}

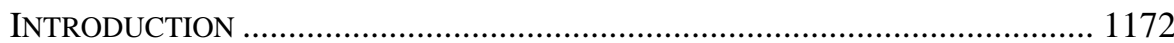

I. AUTHORIAL ATTRIBUTION AND SOCIETY ...................................... 1175

A. Attribution as Incentive ....................................................... 1176

B. Attribution as Consumer Protection ........................................ 1179

C. Attribution as Value............................................................... 1180

II. LEGAL REgUlAtion OF AUTHORIAL ATTRIBUTION ......................... 1185

A. Misattribution and Trademark Law ...................................... 1186

1. Trademark's Purpose.................................................. 1186

2. Authorship as Trademark ............................................. 1193

3. Authorship vs. Trademark ............................................. 1194

B. The Dastar Decision ............................................................ 1200

C. Misattribution and Copyright ............................................. 1210

1. The Meaning of VARA ................................................. 1211

2. Copyright as Collateral Attribution Protection.................... 1214

3. The Attribution/Copyright Mismatch............................... 1217

D. Misrepresentation and Other Legal Mechanisms...................... 1218

III. AUTHORSHIP, CONSUMERS, AND COLLABORATION .......................... 1221

A. Ghostwriting ............................................................. 1221

B. Collaborative Authorship and Social Value ............................. 1228

C. The Limits of Attribution Protection........................................ 1233

1. Extrinsic and Intrinsic Crediting: Vocal Dubbing .............. 1234

2. The Inherent Deceptions of Art .................................... 1238

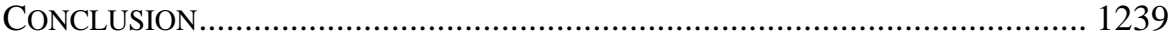

The use of authorial marks in relation to the sale of creative works, like the use of business trademarks in relation to the sale of goods and services, creates social benefits that deserve legal protection. Authorial attribution acts as an incentive to authorial production, provides valuable information to

\footnotetext{
* Assistant Professor of Law, Rutgers School of Law - Camden. Email: greglas@aya.yale.edu. For comments and other help, I would like to thank Barton Beebe, Mike Carrier, Mike Carroll, Carol Chase Lastowka, Ellen Goodman, Brian Hirsch, Dan Hunter, Mark Lemley, Beth Noveck, David Post, Kevin Reitz, Rick Swedloff, Scott Thompson, Polk Wagner, and the diligent editors of the Boston University Law Review. I'd also like to thank the faculty at Rutgers School of Law - Camden, the University of Colorado, the University of Cincinnati, the University of Illinois, and the University of Texas. Special thanks are due to Anne Coughlin, who led me into this wilderness of law and authorship, and to Paul Caron, who let me know that rumors of V.C. Andrews's death were greatly exaggerated.
} 
consumers, and provides additional social benefits that go beyond issues of market efficiency. However, the use of authorial marks, like the use of trademarks, can create social harms. Just as counterfeiters place illegitimate trademarks on goods, exploiters of entertainment markets may be tempted to misattribute authorship. In the United States, such deceptive practices were traditionally subject to the remedial mechanisms of trademark and unfair competition laws. However, in a 2003 decision, Dastar Corporation v. Twentieth Century Fox Film Corporation, the United States Supreme Court held that federal trademark law does not address the misattribution of authorship. The Dastar decision stated that trademark protections were designed to protect the creators of tangible products sold in the marketplace. The Court stated that trademark law was not designed to protect the interests of those who originate creative ideas or communications.

This article explores society's interests in ascertaining the authorship of creative works and explains how those interests both resemble and diverge from standard trademark interests. It concludes that as authorship marks are sufficiently analogous to trademarks, the Dastar approach is misguided. Consumers can and should be protected from misattributions of authorship where such misattributions can easily be remedied by law and where the failure to provide such remedies is likely to lead to significant consumer harms.

\section{INTRODUCTION}

A good name is better than precious ointment. ${ }^{1}$

The earliest known paintings in existence, the wall paintings in the cave of Chauvet, are marked with what seem to be the handprint signatures of the artists who created them over 30,000 years ago. ${ }^{2}$ The intended meaning of these handprints is not clear, but they function to fuse an aspect of the artist's physical identity with the surface of the medium. In essence, they are signatures. Literary signature, which fuses a mark of authorial identity with a text, also has ancient roots. The earliest literary author to sign her name to a work was the ancient Mesopotamian high priestess Enheduanna, who wrote

\footnotetext{
${ }^{1}$ Ecclesiastes 7:1 (King James). See also Scott Paper Co. v. Scott’s Liquid Gold, Inc., 589 F.2d 1225, 1227 (3d Cir. 1978) ('In his classic 'Essay on Walking,' Thoreau expressed the notion that there is nothing in a name. This view has been vigorously rejected by both parties to this [trademark] litigation, not to mention almost all of mankind to whom a name is an important means of identification.”) (citing Ecclesiastes).

${ }^{2}$ Corey Field, Copyright, Technology, and Time: Perspectives on "Interactive" as a Term of Art in Copyright Law, 50 J. Copyright SoC’y U.S.A. 49, 52 (2003). The handprints were created by blowing pigment over the hand held against the rock surface, creating a "negative" print of the hand. Field leads his article with a photograph of the handprints, but he frames the handprints as a proto-copyright assertion of ownership, not signature. Id.
} 
poems circa 2300 B.C. ${ }^{3}$ Centuries later, a version of the Sumerian Epic of Gilgamesh was attributed to the scribe Sin-Leqi-Unninni. ${ }^{4}$ The practice of artistic signature persists today. It is neither a recent nor an exclusively Western phenomenon. ${ }^{5}$ Even where works are not signed by artists, one might argue that all artistic works are intimately bound up with the artist's identity, making the work itself a form of personal signature. ${ }^{6}$ Works of artistic production generally bear traces that may betray the true identity of the creator. ${ }^{7}$ In various small details, authors leave unconscious "fingerprints" on their works that, like handwriting, reveal their personal involvement with the creation. ${ }^{8}$ Just as an actor's facial expressions, style of walking, or manner of speech may be unconsidered yet potentially expressive, so an artist's efforts at self-expression are at least partially governed by unconscious mannerisms. ${ }^{9}$ And obviously, there are some conscious mannerisms that appear in authorial styles - certain skills, themes, interests, and ideologies are reliably associated with particular authors. It should be no surprise that computer-aided algorithmic analysis of handwriting, paint-strokes, and word usage can be used

\footnotetext{
3 Enheduanna, Inanna, Lady of Largest Heart: Poems of the Sumerian High Priestess EnHEdUANNA (Betty De Shong Meador ed. \& trans., 2001).

${ }^{4}$ Sin-Leqi-Unninni, Gilgamesh: Translated from the Sin-Leqi-Unninni Version (John Gardner et al., trans. 1985). Sin-Leqi-Unninni's attributed version was merely a retelling of the much older Gilgamesh story - it would be called a derivative work in the parlance of copyright law.

${ }^{5}$ Cf. Roberta Rosenthal Kwall, The Attribution Right in the United States: Caught in the Crossfire Between Copyright and Section 43(a), 77 WASH. L. REV. 985, 985 (2002) ("The right of attribution recognizes a fundamental truth about human nature.”).

6 See Paul Edward Geller, Toward an Overriding Norm in Copyright: Sign Wealth, Revue InTERnAtionale DU Droit D'Auteur, Jan. 1994, at 3, 21 (“Romantic critics [believed that] by virtue of the creative act ... . authors would necessarily leave the marks of their unique personalities on their works.”).

7 This is not to say that creating such traces is always a goal of artistic production. For instance, those who engage in artistic forgery seek essentially to replicate the known identity traces of another. See Giorgio VAsari, The Lives of the Artists 418, 423-24 (Julia Conaway Bondanella \& Peter Bondanella trans., Oxford Univ. Press 1998) (1549) (recounting how Michelangelo forged old drawings so that he could return the forged copies and retain the originals, and reporting the infamous sale of a forged ancient Cupid for a seventy ducat premium). Also, it is impossible to speak categorically about "artists," some of whom make it a point to defy categorical claims about artistry. For instance, Michel DuChamp and Jeff Koons have simply found objects and duplicated or recontextualized them. See, e.g., Rogers v. Koons, 960 F.2d 301, 305 (2d Cir. 1992) (“In his 'production notes' Koons stressed that he wanted 'Puppies' copied faithfully in the sculpture. For example, he told his artisans the 'work must be just like photo - features of photo must be captured;' later, 'puppies need detail in fur. Details - Just Like Photo!'”).

8 Noah Schactman, Software Detects the True Artist, WIRED News, Nov. 22, 2004, http://www.wired.com/news/technology/0,1282,65794,00.html (explaining how the characteristics of an artist's brush strokes can identify the artist).

${ }^{9}$ See id.
} 
to explore the veracity of claims of authorship. ${ }^{10}$ Because society cares about ascertaining authorship, experts who police the veracity of claimed authorship attributions sometimes employ such techniques. ${ }^{11}$

But do the laws of intellectual property protect indicia of an author's identity? In a recent decision, Dastar Corp. v. Twentieth Century Fox Film Corp., the United States Supreme Court essentially answered "no."12 The Court in Dastar stated that trademark law does not protect against misattributions of authorship because such protections would bring trademark law into conflict with copyright law. ${ }^{13}$ Copyright law is generally understood as the regulatory framework that speaks to artistic creation. Copyright law, however, says very little about the attribution of authorship. ${ }^{14}$ Thus, shorn from trademark law by Dastar and ignored by copyright, markings of authorship are generally not protected by the two primarily federal laws of intellectual property that would conceivably regulate such marks. This does not mean that authorial markings are entirely beyond legal regulation. For instance, authors may use copyright as a lever to demand attributions of authorship. $^{15}$ To some extent, authors may also seek protections against the misuse of their names pursuant to rights of publicity (in states where such protections exist). Consumers deceived by authorial misrepresentations may still make claims of misrepresentation and fraud when they are harmed by false designations of authorship. ${ }^{16}$ But these options create only a spotty, collateral patchwork of protection. In the two places one might reasonably expect to see markings of authorship regulated - the federal intellectual property laws of trademark and copyright - the law is essentially silent.

This article argues that Congress should amend the Lanham Act to reject the Dastar decision and once again apply trademark law to indications of authorship. ${ }^{17}$ The article proceeds as follows: Part I argues that social benefits

${ }^{10} I d$. (describing how invisible pen and brush strokes in artistic works can be detected by computer imaging and attributed to specific artists through algorithmic analyses).

${ }^{11}$ Id. (chronicling a Dartmouth College team's effort to verify the authenticity of a painting). Admittedly, in the case of an artist like Koons, who essentially recontextualizes works and sometimes employs others to do this, such techniques would likely prove ineffective. See supra note 7.

12539 U.S. 23, 36 (2003) (explaining that there is no legal recourse for complaints of plagiarism).

13 Id. at 33.

14 See infra Part II.C.

15 See infra Part II.C.2.

16 See infra Part II.D.

${ }^{17}$ Cf. Jane C. Ginsburg, The Right to Claim Authorship in U.S. Copyright and Trademark Law, 41 Hous. L. REV. 263, 286-306 (2004) (suggesting that the Dastar decision should be remedied by legislative action with regard to moral rights); Laura A. Heymann, The Birth of the Authornym: Authorship, Pseudonymity, and Trademark Law, 80 Notre DAme L. Rev. 1377, 1378 (2005) (observing that trademark designations and authorial attributions share common characteristics and arguing, from the standpoint of First 
from practices of accurate authorial attribution largely track the social benefits provided by source attributions under trademark law. (By contrast, some recent commentary on the Dastar case has focused primarily on how authors benefit from attribution, discussing the "moral rights" of creators to claim rights of attribution. ${ }^{18}$ ) Part II discusses Dastar and explains how theories of trademark and copyright relate to interests in authorial attribution. Part III differentiates social concerns over practices of plagiarism and ghostwriting from issues raised by collaborative authorship. Part III proposes that trademark law should regulate indicia of authorship, but that the scope of authorial attribution protections under trademark law should be crafted as a conservative, non-traditional form of trademark protection.

\section{AUTHORIAL ATTRIBUTION AND SOCIETY}

\section{In the room the women come and go}

\section{Talking of Michelangelo ${ }^{19}$}

Why should trademark law speak at all to the issue of authorial attribution? In answer to this question, I would like to put aside one argument and advance three others. I would like to eschew the claim that trademark law should protect against authorial misattribution because society owes such protection to authors as an ethical, legal, or political imperative. In other words, I am not advocating here for a stripe of authorial "moral rights" protections in response to the Dastar decision. ${ }^{20}$ This article does not oppose such arguments. ${ }^{21}$

Amendment law and literary theory, that the law must recognize "the essential pseudonymity of all statements of authorship").

18 See Ginsburg, supra note 17, at 265 ("Reputation is critical to a person who follows a vocation dependent on commissions from a variety of clients. Success breeds success, but only if the first success is known to potential clients.”); David Nimmer, The Moral Imperative Against Academic Plagiarism (Without a Moral Right Against Reverse Passing Off), 54 DePaul L. Rev. 1, 77 (2004) ("In sum, there is in the United States, and there should continue to be, a moral right against passing off. As a general matter, by contrast, the reverse should be limited to specialized settings, such as academe, where attribution lies at the core of the raison d'etre for the creation of works.”); Justin Hughes, American Moral Rights and the Dastar Decision 3 (Cardozo Legal Studies, Working Paper No. 96, 2004), available at http://ssrn.com/abstract=618783 (understanding Dastar in the context of moral rights and the Berne Convention).

19 T.S. Eliot, The Love Song of J. Alfred Prufrock, reprinted in T.S. Eliot, The Complete Poems and Plays 1909-1950 3, 4 (1952).

20 The United States is required, by treaty, to protect such rights. See John T. Cross, Giving Credit Where Credit Is Due: Revisiting the Doctrine of Reverse Passing Off in Trademark Law, 72 WASH. L. REV. 709, 761-62 (1997) (discussing and critiquing U.S. efforts to comply with the requirements of the Berne Convention); Ginsburg, supra note 17, at 265 ("[T]he Berne Convention ... requires that Member States protect other Members' authors' 'right to claim authorship.'”); Kwall, supra note 5, at 1003 (discussing attempts to 
However, framing the authorial attribution question along these lines runs the risk of casting attribution as a struggle between the rights and interests of artists and the rights and interests of state and society. Attribution rights under such an analysis become a zero-sum game in which authors and artists must find some foothold (ethical, legal, or rhetorical) by which to obtain entitlements from society that are currently lacking. However, if we focus on the manner in which authorial attribution practices benefit society, we can move beyond the standard tug-of-war.

Along those lines, I would like to make three brief observations with regard to how the application of trademark to authorial attribution might benefit society. The first two benefits align fairly well with the benefits commonly associated with trademarks: facilitating the production of quality products and reducing consumer search costs. ${ }^{22}$ A third argument is that accurate authorial attribution benefits society because it is a type of information that has a special social value.

\section{A. Attribution as Incentive}

With regard to the first argument, it is clear that authorial attribution can function much like a trademark interest. If artists seek riches, they must compete for patrons, prizes, and the favor of the public. In order to win in this competition, artists must attempt to ensure that their works are of high quality, and that prospective consumers will associate their new works with their established reputations. If artists can ensure attribution of their works, artists producing better quality will gain public goodwill and reap the benefits of their investments in producing works of higher quality. ${ }^{23}$ This recognition and goodwill can lead to greater opportunities for employment and contractual leverage. Authorial attribution is thus a mechanism for ensuring that greater profits flow to those producing superior products.

But the incentive role of attribution is not merely financial, as generally

secure attribution rights using the Lanham Act).

${ }^{21}$ Indeed, I generally agree with Jane Ginsburg, Roberta Kwall, and others who suggest that copyright law needs to be more attuned to protecting the interests of authors, not simply those who are currently benefiting from copyright entitlements. See, e.g., Jane C. Ginsburg, The Concept of Authorship in Comparative Copyright Law, 52 DePAul L. Rev. 1063, 1092 (2003) (criticizing the work for hire paradigm that secures rights on a basis other than authorship).

22 See William M. Landes \& Richard A. Posner, Trademark Law: An Economic Perspective, 30 J.L. \& ECON. 265, 268-73 (1987) (applying a comprehensive economic model to many of the doctrines of trademark law in an attempt to understand its costs and benefits); see also Barton Beebe, Semiotic Analysis of Trademark Law, 51 UCLA L. REV. 621, 623-24 (2004) (identifying the Chicago School analysis as the dominant theory of trademark protection).

23 See Stacey L. Dogan \& Mark A. Lemley, Trademarks and Consumer Search Costs on the Internet, 41 Hous. L. REV. 777, 787 (2004) ("Sellers benefit because they can invest in goodwill with the knowledge that others will not appropriate it.”). 
posited in the case of trademark protections. ${ }^{24}$ In the case of authorship, the benefits reaped by artists from attribution are social and psychological as well. ${ }^{25}$ In the past, these social and psychological benefits may have even been the primary reward provided in return for artistic production - simply because no other significant reward existed. A desire for the immortality of fame might have played some part in the creative efforts made by Enheduanna, Sin-LeqiUnninni, and Homer. In the era of mass media and diffused corporate control of trademarks, we do not often think of attribution as providing this kind of benefit as an incentive to greater production. The legal academy generally continues to regard copyright law's financial incentives as the primary engine driving creative production, even though there are many reasons to be suspicious of this claim. ${ }^{26}$ When copyright law is viewed against the panorama of artistic creativity throughout human history, it is revealed to be a very recent legal ordering birthed by technological revolution, fueled in its expansion by particular business models, and perhaps best explained as a means of providing incentives to distribute works through technologies of reproduction. ${ }^{27}$ Indeed, some have argued that copyright is primarily attuned to protecting the interests of publishers, not the interests of authors as artists. ${ }^{28}$

Socially valuable artistic production obviously predated copyright's birth in the seventeenth century. Copyright was instituted, in a rather limited form, more than a century after Michelangelo's death. ${ }^{29}$ This is not to say that the

${ }^{24}$ Cf. Dogan \& Lemley, supra note 23, at 799 n.84 (noting that “[n]oneconomic justifications for trademark law are rare”).

25 The strong allure of fame to artists does not require a lengthy footnote. Suffice it to say that a popular movie, song, and television series about a school for young performing artists was not entitled Profit. See Roberta Rosenthal Kwall, Fame, 73 IND. L.J. 1, 1 n.1 (1997) (citing the television series Fame and the associated movie and song). Many scholars have argued that the pursuit of fame motivates artistic creativity. See Cross, supra note 20, at 764-66 (“[M]any artists are unique in that they want recognition for recognition's sake.... [F]ame itself provides part, or maybe even all, of the motivation for creative activity.”); Stuart P. Green, Plagiarism, Norms, and the Limits of Theft Law: Some Observations on the Use of Criminal Sanctions in Enforcing Intellectual Property Rights, 54 HASTINGS L.J. 167, 174 (2002).

${ }^{26}$ Dan Hunter \& F. Gregory Lastowka, Amateur-to-Amateur, 46 WM. \& MARY L. REV. 951, 991-92 (2005) (observing that copyright, ironically, is largely irrelevant to the production of legal scholarship).

${ }^{27}$ Id. at 979-985 (discussing the application of copyright law to various copying technologies); F. Gregory Lastowka, Free Access and the Future of Copyright, 27 RUTGERS COMP. \& TECH. L.J. 293, 293-97 (2001) (describing modes of distribution and explaining changes resulting from digital technology).

${ }^{28}$ See Jane C. Ginsburg, How Copyright Got a Bad Name for Itself, 26 ColuM. J.L. \& ARTS 61 (2002).

29 See Stephen Breyer, The Uneasy Case for Copyright: A Study of Copyright in Books, Photocopies, and Computer Programs, 84 HARV. L. Rev. 281 (1970). Indeed, copyright was extended to protect works of visual art only a little more than a century ago. EDWARD 
quest for fame and attribution was the only thing that drove Michelangelo's efforts - the motivations for his work were complex. ${ }^{30}$ As his artistic genius and reputation grew, his personal profits grew in equal measure. ${ }^{31}$ Yet it is interesting to note how Michelangelo's desire for a perfect reputation, at various points in his life, eclipsed his desire to increase his wealth. ${ }^{32}$ Giorgio Vasari, a contemporary of Michelangelo, explained how Michelangelo destroyed valuable works that he believed to be of inferior quality:

$[\mathrm{H}] \mathrm{e}$ often abandoned his works, or rather ruined many of them ... just before his death he burned a large number of his own drawings, sketches, and cartoons to prevent anyone from seeing the labours he endured or the ways he tested his genius, for fear that he might seem less than perfect .... .33

Michelangelo could certainly have sold off these inferior drawings and sketches in order to benefit himself or his friends. Instead, where his reputational interests and financial interests appeared to diverge, he protected his reputation. ${ }^{34}$ Some might lament the loss of those destroyed drawings, and see Michelangelo's pursuit of a perfect reputation as excessive. But the paradox is that the reputation dynamic that drove Michelangelo to destroy his work was also the dynamic that drove him to strive for perfection and to create his most celebrated works. Michelangelo decided that only a certain quality of artistic work would further his reputational interests, and it was this type of work that he struggled to produce. ${ }^{35}$ If reputation and attribution played a part in driving Michelangelo to create his celebrated works, society ultimately benefited from accurate authorial attribution practices. ${ }^{36}$

Samuels, The Illustrated Story of Copyright 11-15 (2000); Paul Edward Geller, Copyright History and the Future: What's Culture Got to Do With It?, 47 J. CoPYRIGHT SoC’y U.S.A. 209, 215 (2000) (describing the origins of English copyright law in fifteenthcentury monopolies on printing).

30 George Bull, Michelangelo: Life, Letters, and Poetry 28-73 (George Bull \& Peter Porter eds. \& trans., 1987) (translating and updating Ascanio Condivi’s account).

${ }^{31} \mathrm{Id}$.

32 Biographical accounts suggest that while Michelangelo was generally reclusive and sometimes a bit miserly, he was very concerned with his artistic reputation. VASARI, supra note 7. See also Bull, supra note 30, at 61-62 (translating Ascanio Condivi); DiANE STANLEY, Michelangelo 24, 39 (2000) (detailing how Michelangelo was a perfectionist in his work, but shunned riches). It is interesting to note that Michelangelo did not fix his name to his works, and signed only the Pieta statue. However, he signed that work not on the base, as was customary, but on the prominent ribbon that crosses the Virgin's chest at eye level. LAURIE AdAMS, ItALIAN RENAISSANCE ART 316 (2001).

33 VASARI, supra note 7, at 472.

${ }^{34}$ Id. (describing how Michelangelo destroyed many of his own works).

${ }^{35} \mathrm{Id}$.

${ }^{36}$ See supra note 32. 


\section{B. Attribution as Consumer Protection}

A second argument for regulation of authorial attribution is also closely related to the standard justifications for trademark regulation. Authorial attribution furthers the interests of consumers by reducing the costs of searching for creative content. As Mark Rose has noted, a mark of authorship functions much like a trademark - it signals a certain predictable quality and type of associated work. ${ }^{37}$

In the fiction sections of libraries and bookstores, books are generally arranged alphabetically by the last names of their respective authors. The names of these authors also appear on the covers and spines of the works, sometimes encompassing the entire top half of a book's cover. ${ }^{38}$ Indicia of authorship must be conveying some form of valuable information to consumers. If they were not, the existence of these bold statements of authorship would be mysterious. For instance, other products for sale, including those protected by other species of intellectual property laws, are not generally emblazoned with the names of their creative originators and inventors. Arthur Fry, the creative inventor of Post-it ${ }^{\circledR}$ notes, certainly wouldn't mind being credited with his invention. ${ }^{39}$ He surely would not object if office supplies were sorted by his last name (i.e., under "F" for Fry). Inventors like Fry likely share the same pride in their inventions that authors possess in the novels they write. But to emblazon inventor names on items for sale would probably strike us as absurd in the case of office products. Most of us just don't care who came up with the idea for the Post-it ${ }^{\circledR}$ note - the identity of the creator is severable from the product.

Yet works of creative authorship are different. In the case of creative works, indicia of authorship can provide special value to consumers. From a consumer standpoint, particular authors are believed to be associated with works possessing certain intrinsic qualities. ${ }^{40}$ For example, consumers are likely to believe that all novels by the authors Tom Clancy and V.C. Andrews possess certain distinctive qualities. Like trademarks, these authorial attributions enable consumers who are searching for particular types and

37 Mark Rose, Authors And Owners 1 (1993) (commenting that an author is “a kind of brand name, a recognizable sign that the cultural commodity will be of a certain kind and quality”).

38 See, e.g., Michael Crichton, Congo (Avon Books 2003) (evidencing the importance of an author's name by displaying it as large as the title on the cover of a book).

39 Arthur Fry and a colleague were responsible for the invention of 3M’s Post-it ${ }^{\circledR}$ Notes. See U.S. Patent No. 5,194, 299 (filed Dec. 31, 1986); Mark F. Grady \& Jay I. Alexander, Patent Law and Rent Dissipation, 78 VA. L. Rev. 305, 331-32 (1992).

40 See Rose, supra note 37; Cross, supra note 20, at 762 (“[T]he artist's name provides some indication of the quality of the work.”); Diana Elzey Pinover, The Rights of Authors, Artists and Performers Under Section 43(a) of the Lanham Act, 83 TRADEMARK REP. 38, 47 (1993) (acknowledging the converse proposition that an author's early work, or poorer quality work, may detract from the value of her name as a mark). 
qualities of products to find those products that they consider more appealing. ${ }^{41}$ While authors' names are not trademarks per se and not all consumers value authorial indicia in all instances, author names can act very much like trademarks by providing useful information to consumers selecting among competing products. ${ }^{42}$

\section{Attribution as Value}

While the prior two sections sought to justify the social value of authorial attribution by appealing to incentive effects or utility in reducing consumer search costs, there is another social value provided by attribution. Society has expressed an entirely independent, somewhat sui generis interest in demarcating and ascertaining authorship, unrelated to any instrumental and utilitarian effects that authorial attribution may have on markets and production. ${ }^{43}$ In other words, a correct authorial attribution is a thing of value in itself.

To take the example of Michelangelo again, we can assume that the price of a drawing by Michelangelo will be higher than the price of a work by other artists who were his contemporaries. Are Michelangelo's drawings of a better quality? The answer is generally yes, but the interesting point to see here is that a hypothetical drawing attributed to Michelangelo would be valued more highly than a hypothetical work by one of his contemporaries even if the two hypothetical works were identical. ${ }^{44}$ A lousy Michelangelo drawing is a valuable chattel - more valuable than the same lousy drawing that isn't attributed to Michelangelo. Michelangelo's attribution, therefore, does not simply convey information about the value of the work to which the attribution is attached. The attribution, to some extent, creates the value. ${ }^{45}$

One might argue that the value of the object in this case stems simply from the value of celebrity aura associated with a tangible artifact. ${ }^{46}$ Michelangelo's

${ }^{41}$ Cross, supra note 20, at 753-54 (positing that discovering the source of a product is a quick way for a consumer to evaluate the product).

${ }^{42}$ See infra Part II.A and Part III.

43 See infra note 45 and accompanying text.

44 Even Michelangelo's attempted forgeries, if recognized as such, would likely command a higher value today than they would were they authentic. See supra note 7.

45 This tracks roughly with another, much less venerable and less accepted vein in trademark theory: the anti-dilution theories of trademark protection, codified in federal law at 15 U.S.C. § 1125(c) (2000). The general notion of these theories is that the law should protect a trademark signifier's value in itself, independent of its associative value which stems from linking the mark with a particular associated quality of underlying goods or services. See Beebe, supra note 22, at 684-87 (reviewing the anti-dilution theories as the basis for trademark protection); Frank I. Schechter, The Rational Basis of Trademark Protection, 40 HARV. L. REV. 813 (1927), reprinted in 60 TRADEMARK REP. 334, 336-38 (1970) (arguing that a trademark has value apart from the signification of a source).

46 See Walter Benjamin, The Work of Art in the Age of Mechanical Reproduction 
celebrity could create similar value in paintbrushes and chisels that he employed to create his works. Artifacts that are associated with any figure of fame (say, Benjamin Franklin's eyeglasses or a dress worn by Marilyn Monroe ${ }^{47}$ ) often have a fetishistic or historical value to consumers that seems strangely disproportionate to any detached measure of the object's utility. ${ }^{48}$ But the value created by authorship is not limited to tangible fetishes - a person who framed a supposed Michelangelo print might discount the value of the reproduction if the original was subsequently determined to be a forgery. The point here is that authorship matters to the public because it places a work in a particular social context. Indeed, even when objects are not for sale and artists and authors are long dead, society will often police issues of authorial attribution for their own sake. Was De Doctrina Christiana the work of Milton? Was Titus Andronicus the work of Shakespeare? We might ask why these questions even matter - but we can't deny that they do matter to many people and that many intelligent people engage in vigorous debates over these exact questions. In the case of Shakespeare, scholarly wrangling over authorship rises to the level of a recognized field of academic research. ${ }^{49}$ This type of social interest in attribution admittedly isn't the rule for most artists and authors, but neither is it all that rare. The scholar Kathryn Lindskoog, for instance, devoted much of her life to exposing what she believed to be misattribution marring the reputation of C.S. Lewis. ${ }^{50}$ The general point here

(1937), in IlLuminations 219, 223 (Hannah Arendt ed., Harry Zohn trans., 1968) (1955) (discussing how mechanical reproduction transformed the nature of artistic objects by removing the aura of originality).

47 See, e.g., Brendan Walsh, Collecting Marilyn: Blonde Bombshell Inspires Local Man's $\$ 10,000$ Search, Corpus Christi CALler-Times (Tex.), Sept. 18, 2001, available at http://www.caller2.com/2001/september/18/today/fea-livi/11808.html (“At Christie’s auction house in 1999, a two-day auction of Monroe's personal belongings netted more than $\$ 13.4$ million. The most expensive item, the dress Monroe wore when she sang 'Happy Birthday’ to President Kennedy in 1962, went for \$1.26 million.”).

48 Cf. Margeret Radin, Property and Personhood, 34 Stan. L. REV. 957, 959 (1982) (commenting how the primary value of certain objects may derive from notions of self and personhood).

49 James D.A. Boyle, The Search for an Author: Shakespeare and the Framers, 37 AM. UnIV. L. REV. 625, 627 (1988) (noting that "[t]here are some fifty-six claimants to Shakespeare's throne - some of whom are supposed to have worked alone, while others are supposed to have collaborated in the most unlikely assemblies"); see also The Shakespeare Fellowship, http://www.shakespearefellowship.org/index.html (last visited Sept. 9, 2005) (collecting internet resources on the issue of Shakespearean authorship). Even law reviews have recently joined the fray. See Thomas Regnier, Comment, Could Shakespeare Think Like a Lawyer? How Inheritance Law Issues in Hamlet May Shed Light on the Authorship Question, 57 U. MiAmi L. REV. 377, 377 (2002) (examining the use of legal terms in Shakespeare's works to ascertain the correct identity of the author).

${ }^{50}$ Lindskoog had alleged that the Lewis estate has tampered with the canon, most notably in the case of the posthumously published Lewis novel, The Dark Tower (1983), a 
is that accurate authorial attribution can be relevant to people other than the authors of works. It can be relevant to society for reasons that cannot be captured in terms of market efficiencies.

These broader social interests in ascertaining and denoting authorship operate independently of the author, persist after the death of the author, and at times fly in the face of the "moral rights" approach that focuses on protecting the personal interests of the artist. ${ }^{51}$ George Maciunas is a good example.52 Maciunas was a twentieth-century modern artist who was ideologically opposed to what he saw as the tradition of the self-absorbed, privileged, bourgeoisie artist separated from the working class. ${ }^{53}$ He attempted to destroy this division by forming a movement within which individual artistic attributions (and copyright) would be forbidden. He demanded that all artists in his revolutionary enterprise would produce under the name FLUXUS. ${ }^{54}$ Commentators today, however, routinely identify George Maciunas as the artistic originator of the FLUXUS group, and point to the respective involvements of John Cage, Yoko Ono, June Paik, Al Hansen, and others. ${ }^{55}$ The success of the FLUXUS movement in attracting attention was the cause of its failure to achieve its goals. ${ }^{56}$

As Giorgio Vasari's famous tome on the lives of his contemporaries indicates ${ }^{57}$ society is interested not only in the works of authors and artists, but also in exploring the personalities and lives of those who have created socially prominent works. The reader's impulse to learn about the author can and does operate against the interests of the author in some cases. Maciunas is one

very strange work of science fiction. KATHRYN ANN LINDSKOOG, SLEUTHING C. S. LEWIS: More Light IN THE Shadowlands (2001); see also Scott McLemee, Holy War in the Shadowlands, The Chron. Of Higher Educ., July 20, 2001, at A12 (describing Lindskoog's allegations of tampering by Lewis's estate).

51 See Berne Convention for the Protection of Literary and Artistic Works, art. 6bis, Sept. 9, 1886, revised at Paris July 24, 1971, 25 U.S.T. 1341, 828 U.N.T.S. 221 (protecting the moral rights of artists by mandating rights of attribution and integrity).

52 ERIKa Doss, Twentieth-Century AMERICAN ART 148 (2002) (discussing the work of George Maciunas).

53 Id.

54 As Maciunas explained in a letter to a friend in 1964, "Eventually we would destroy the authorship of pieces and make them totally anonymous - thus eliminating artist's 'ego.' Author would be FLUXUS." THEORIES AND DOCUMENTS OF CONTEMPORARY ART: A SourceboOK OF ARTists’ Writings 725-28 (Peter Selz \& Kristine Stiles eds., 1996) (letter from Maciunas to Thomas Schmit circa 1964).

55 Doss, supra note 52, at 148 (observing how Maciunas coined "Fluxus"); THOMAs Hoving, ART FOR DuMmies 180 (1999) (noting “the Fluxus events of George Maciunas”).

56 See Hoving, supra note 55, at 180 (associating Fluxus with Maciunas despite Maciunas's desire for anonymity in his art).

${ }^{57}$ VASARI, supra note 7 (remarking on the personal lives of contemporary artists with whom Vasari was familiar). 
prominent example, and J.D. Salinger presents another. ${ }^{58}$ Readers have always been interested in exploring the personality of the artist as a means to appreciate and further explore the work. ${ }^{59}$ The practice of exploring and appreciating literature by exploring the identity of the author was, prior to the last century, an acceptable academic practice. Only with the ascendancy of New Criticism was authorial hagiography denigrated. ${ }^{60}$ New Criticism, partaking in the broader formalistic rigor of modernism, isolated the text from the author. The inevitable result of this effort was, perhaps unsurprisingly, the collapse of the concept of any fixed meaning in texts and the publication of an essay (authored by Roland Barthes) where the author was proclaimed dead. ${ }^{61}$ Michel Foucault suggested that authorship acted as an interpretive construct primarily serving to limit the freedom of potential meanings in a text. ${ }^{62}$ Yet throughout all this revolution and interpretive upheaval, the public still was buying People Magazine and reading about the personal lives of John Grisham, Steven King, and Tom Clancy. In some respects, new media made

58 Of course, one might question the true motives of Maciunas and Salinger. See, e.g., Alex Beam, J.D. Salinger, Failed Recluse, Slate, June 29, 1999, http://slate.msn.com/id/31263/ ("If Salinger really wants to be left alone, he is going about it in a very strange way. He doesn't live in a gated community. He summons perfect strangers into his hideaway. He sues people, and then phones the media to spread the story.”).

59 See Robert H. Rotstein, Beyond Metaphor: Copyright Infringement and the Fiction of the Work, 68 CHI.-KeNT. L. REV. 725, 734-35 (1993) (explaining the historical importance to literary criticism of studying the life and personality of the author).

60 See id. at 734-35 ("New Criticism ... developed as a reaction to the Romantic notion of genius and the academic pre-eminence of historical study. In New Critical theory, 'work' replaced 'author' as the central unifying force in literary criticism. This version of modernist thought conceived of the creative work as autonomous and ahistorical.”). While New Criticism is clearly an ideology of interpretation that might be disputed, romantic authorship (which might be aligned with a more central notion of authorship) has probably had a more pronounced effect on our system of intellectual property. It is equally susceptible to critique. See James Boyle, Shamans, Software, and SpleEns: Law and the Construction of the Information Society x-xi (1996); Boyle, supra note 49 (exploring the importance of determining the author of a work in order to interpret the meaning of his or her writing); Peter Jaszi, Toward a Theory of Copyright: The Metamorphoses of “Authorship”, 1991 DuKE L.J. 455 (commenting on how the notion of authorship has been used in the development of intellectual property law); David Lange, At Play in the Fields of the Word: Copyright and the Construction of Authorship in the PostLiterate Millennium, 55 LAW \& CONTEMP. ProBs. 136 (1992) (describing how new technologies are eroding intellectual property and the constraints on authorship).

61 Roland Barthes, The Death of the Author, in Image-Music-Text (Stephen Heath, trans., 1978) (proclaiming that the reader, not the writer, should be at the center of criticism).

62 See Michel Foucault, What Is an Author?, in The Foucault ReAder 101, 107 (Paul Rabinow ed., 1984) (asserting that the notion of "author" performs a classification and interpretative function for works, beyond a mere identification role). 
the identity of the artist an even greater public concern. For instance, in the realm of music, MTV made the combination of image, celebrity, and marketing triumph over the pure appreciation of sound. From a societal perspective, the author never died - and she was never even seriously ill. Well-known post-authorship figures such as Michel Foucault and Jacques Derrida found their personalities and life histories deeply intertwined with prevalent social interpretations of their publications. ${ }^{63}$ When society cares about a creative work, it cares about the work's author. Making the connection between personal identity and creative work has always been a natural move.

Perhaps the clearest evidence that society still cares very much about authorial attribution is our reactions to plagiarism. While credit-claiming for the words of others is a fairly common practice, ${ }^{64}$ it is one that is generally censured by society. Social norms that condemn plagiarism are, essentially, social norms that strongly condemn authorial misattribution. ${ }^{65}$ The conventional legal understanding of the term "plagiarism" is that it is not a violation of any law, but a violation of the norm of accurate authorial attribution. ${ }^{66}$ Even in this postmodern era, anti-plagiarism norms remain quite

${ }^{63}$ See Wikipedia: Michel Foucault, http://en.wikipedia.org/wiki/Michel_Foucault (last visited Aug. 12, 2005); Wikipedia: Jacques Derrida, http://en.wikipedia.org/wiki/Jacques_Derrida (last visited Aug. 7, 2005).

64 See Roger Billings, Plagiarism in Academia and Beyond: What Is the Role of the Courts?, 38 U.S.F. L. REV. 391, 396 (2004) (“Almost everyone plagiarizes. Nearly every time a joke is told it is borrowed without attribution. Abraham Lincoln routinely retold jokes he borrowed from magazines. Ministers and pastors borrow sermons from each other without attribution; easily available collections of sermons all but invite plagiarism.”); Lisa G. Lerman, Misattribution in Legal Scholarship: Plagiarism, Ghostwriting, and Authorship, 42 S. TEX. L. REV. 467, 468 (2001) ("It is as if admission to the bar is like walking through a looking-glass. On one side, plagiarism is considered to be the most egregious variety of dishonesty. On the other side, the use of the words and ideas of others without attribution is not regarded as raising any ethical concern.”).

65 Anonymous, A Funny Thing Happened on the Way to the Web: A Cautionary Tale of Plagiarism, 93 LAW LiBR. J. 525, 525 (2001) ("Like most of us who manage to get something we've written published, I am always gratified if my work is cited or found useful enough to be quoted by others. When confronted with this blatant theft of my work, however, I was shocked and genuinely hurt.”).

66 Randall P. Bezanson, Speaking Through Others' Voices: Authorship, Originality, and Free Speech, 38 WAKE FOREST L. REV. 983, 1075 (2003) ("Plagiarism consists of the conscious taking of another's specific words and ideas as one's own without any attribution."); Billings, supra note 64, at 392 ("Plagiarism is the borrowing of someone else's work without attribution.”); Robert D. Bills, Plagiarism in Law School: Close Resemblance of the Worst Kind?, 31 SANTA ClaRA L. REV. 103, 108 (1990) ("Borrowing from another's work with attribution does not constitute an act of plagiary because there is no pretense of originality.”); Terri LeClercq, Failure to Teach: Due Process and Law School Plagiarism, 49 J. LEgal Educ. 236, 245 (1999) (“[F]ailure to attribute is key to plagiarism”); Lisa G. Lerman, Misattribution in Legal Scholarship: Plagiarism, Ghostwriting, and Authorship, 42 S. TEx. L. REV. 467, 475 (2001) (“To claim authorship of 
strong. ${ }^{67}$ When a public figure is charged with plagiarism, the public concern is not primarily about protecting the possessory interests of the "owner" of the stolen words. Instead, society sees itself as the victim of duplicity and is interested in passing judgment on the character of the plagiarist. Recent scandals relating to the authorship practices of Stephen Ambrose, Doris Kearns Goodwin, Laurence Tribe, and Charles Ogletree all demonstrate that the media is confident that the public wants to hear news about high-profile plagiarism. ${ }^{68}$ The morality play is clearly the attraction here - in most of these cases, the average citizen is unlikely to have ever read the materials that were claimed to have been plagiarized.

\section{LEgAl REgUlation OF AUthORIAL ATtRIBUtion}

Given social interests in attribution, we might expect the law of the United States to play some regulatory role in the realm of authorial attribution. At the turn of the last century, the law did play this role. ${ }^{69}$ Social protections against

work that was in fact authored by another is plagiarism.”); Laurie Steans, Copy Wrong: Plagiarism, Process, Property, and the Law, 41 Copyright L. Symp. 43, 58 (1998) ("Plagiarism is not necessarily copyright infringement, nor is copyright infringement necessarily plagiarism.”).

67 The gulf between literary theory and contemporary social intuitions with regard to misattributive practices is rather pronounced - New Critical approaches to textual interpretation don't seem to square well with modern cultural beliefs about inchoate rights to appropriate credit. Compare, e.g., Perspectives on Plagiarism and Intellectual Property in A Postmodern World (Lise Buranen \& Alice M. Roy eds., 1999) (arguing that prohibitions against plagiarism are problematic in light of contemporary literary theories), and K.K. RuthVEN, FAKING LiterAture i (2001) (arguing that "the production of a literary forgery is an act that reveals the spurious nature of literature itself”), with Lisa Lerman, Misattribution in Legal Scholarship: Plagiarism, Ghostwriting, and Authorship, 42 S. TEX. L. REV. 467, 492 (2001) ("This examination of the question of authorship suggests that there is no justification for a professor to take the work of a research assistant and publish it as his own.”), and Thomas Mallon, Stolen Words: The Classic BooK on PlagiaRISM 243 (Harcourt, Inc. 1st ed. 2001) ("[A]cademics remain curiously willing to vaporize the whole phenomenon of plagiarism in a cloud of French theory.”).

68 Joseph Bottum, Laurence Tribe and the problem of borrowed scholarship, THE WEEKLY STANDARD, Oct. 4, 2004, available at http://www.weeklystandard.com/Content/Public/Articles/000/000/004/674eijco.asp (calling a book by Tribe on constitutional law "uncomfortably reliant” on another scholar's work); Chris Suellentrop, Dead Man Writing: How to Keep Writing Your Late Father's Books, SLATE, Feb. 20, 2003, http://slate.msn.com/id/2078980/ (stating that historian Stephen Ambrose employed members of his family to write portions of his books).

${ }^{69}$ See Lauren Wise, King v. Innovation Books: An Analysis of Credit Attribution with Respect to the Lanham Act, 1 VILL. SPORTS \& ENT. L.J. 147, 147 (1994) (stating that "[a]uthors may sue under [the Lanham Act] when an erroneous credit is issued"); see also Smith v. Montoro, 648 F.2d 602, 608 (9th Cir. 1981) (finding Lanham Act cause of action where the plaintiff actor's name was omitted and his role attributed to another in film credits); Williams v. UMG Recordings, 2003 U.S. Dist. LEXIS 18400, at *17 (C.D. Cal. 
deceptive authorial attributions were not well defined, but they did exist under the rubric of trademark law. ${ }^{70}$ However, the Supreme Court's recent decision in Dastar Corp. v. Twentieth Century Fox Film Corp. has essentially eviscerated the primary basis of those protections. ${ }^{71}$ In this Part, I will look at the law that addresses claims involving authorial attribution. First I will turn to trademark law. Then I will explain how the Supreme Court's decision in Dastar affected trademark protections. Following that, I will discuss copyright as an alternative basis for protection. Finally, I will consider how authorial attribution might still find some protections under various other regimes.

\section{A. Misattribution and Trademark Law}

\section{Trademark's Purpose}

Trademark law is a part of the broader law of unfair competition. ${ }^{72}$ Contemporary trademark law originated in English common law, and the early trademark cases involved the regulation of products created by guilds and stamped with unique marks of origin. ${ }^{73}$ These marks of a trade signaled that a particular collective or individual identity had manufactured a particular tangible product. ${ }^{74}$ Trademark law evolved to protect the veracity of these

Aug. 11, 2003) (holding that the Lanham Act claim to authorial attribution in the documentary credits is precluded by the Supreme Court's Dastar decision); Follett v. New American Library, 497 F. Supp. 304, 313 (S.D.N.Y. 1974) (granting plaintiffs' motion because "the Lanham Act was designed to prevent the presentation of an author's work to the public in a distorted form and to protect the public and artist from misrepresentations of the artist's contribution to a finished work").

70 See Smith, 648 F.2d at 608; Williams, 2003 U.S. Dist. LEXIS 18400, at *17; Follett, 497 F. Supp. at 313.

71539 U.S. 23, 38 (2003).

72 Moseley v. V Secret Catalogue, Inc., 537 U.S. 418, 428 (2003) (declaring that "[t]raditional trademark infringement law is a part of the broader law of unfair competition”).

${ }^{73}$ See Edward S. Rogers, Some Historical Matter Concerning Trademarks, 9 Mich. L. REV. 29, 33 (1910) ("As early as the thirteenth century, the copying of valuable marks became so common and so injurious that infringement was made a misdemeanor and in some cases even a felony and was punished in the barbarous manner characteristic of the times. The Elector Palatine in the Fourteenth Century [sic] issued an edict which, after reciting that the sale of spurious wine was the most outrageous form of deceit, punished by hanging any innkeeper who sold ordinary wine as Rudesheimer.”).

74 See Frank L. Schechter, The Historical Foundations of the Law Relating to TRADE-MARKS (1925) (discussing the historical origin of trademarks for regulation as used by guilds); Sidney A. Diamond, The Historical Development of Trademarks, 65 Trademark Rep. 265, 280 (1975). But see Steven Wilf, Who Authors Trademarks?, 17 CARDOZO ARTS \& ENT. L.J. 1, 1-2 (1999) (suggesting that Schecter's focus on the development of trademarks as guild marks ignores the importance of societal interests in trademark authorship). 
attributions. ${ }^{75}$ It thus protected primarily against a particular form of consumer fraud, the marking of trade goods with the mark of a competitor in a manner that deceived the public as to the source of the product for sale. ${ }^{76}$ In 1946, the federal Lanham Act generally codified the common law of trademark. ${ }^{77}$ The reach of the Lanham Act's federal interpretation extends beyond the federal sphere, however, because many state unfair competition laws are interpreted congruently with federal Lanham Act decisions. ${ }^{78}$

\section{FIGURE 1}

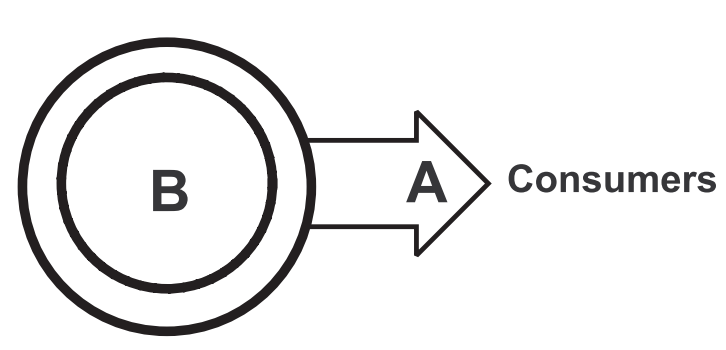

Figure 1 illustrates the most common situation of trademark infringement, "passing off."79 A product is, in some sense, an essential "B" product (meaning it is produced by entity $\mathrm{B}$, sponsored by entity $\mathrm{B}$, or has qualities associated with B) and that product is deceptively marked "A" (suggesting it is produced by entity A, sponsored by entity A, or has qualities associated with A's goods). The business that uses (and/or has registered) trademark "A" sues party $\mathrm{B}$, the sellers of the competing product. ${ }^{80}$ A alleges that B's practices are

75 See Dastar Corp. v. Twentieth Century Fox Film Corp., 539 U.S. 23, 34 (2003) ("Federal trademark law ... helps assure a producer that it and not an imitating competitor will reap the financial, reputation-related rewards associated with a desirable product.”); see also Lee Burgunder, Trademark and Copyright, How Intimate Should the Close Association Become?, 29 SANTA ClaRA L. ReV. 89, 94 (1989).

76 See Dastar, 539 U.S. at 34.

77 See 15 U.S.C. §§ 1051-1127 (2000) (codifying sections 1 to 46 of the Lanham Act).

78 See, e.g., Williams v. UMG Recordings, 2003 U.S. Dist. LEXIS 18400, at **26 (C.D. Cal. Aug. 11, 2003) ("The Ninth Circuit has consistently held that state law unfair competition claims are 'congruent' with Lanham Act claims; Plaintiff's putative unfair competition claim would fail for the same reasons his Lanham Act claim fails.”).

79 See Dastar, 539 U.S. at 28 n.1 (defining passing off); RESTATEMENT (THIRD) OF UNFAIR COMPETITION $§ 4$ (1995).

80 There is a question of standing here. While the Lanham Act's broader provisions literally read that a claim is available to "any person who believes that he or she is or is likely to be damaged" by a misrepresentation, these provisions have been limited by some 
likely to confuse consumers into believing that the B products are produced or sponsored by A. This damages A through lost sales and conceivably lost goodwill. It also damages consumers because they are not receiving the " $\mathrm{A}$ " sponsored or crafted product they desired. This is classic "passing off" - B is attempting to pass off its own product as A's product. ${ }^{81}$ In order to prevail in a trademark infringement case, A must demonstrate that consumers are likely to be confused as to the source or origin of B's product. ${ }^{82}$ A's rights are not limited to an exact reproduction of A's mark, but A may also prevail when B uses look-alike or sound-alike marks that are also likely to confuse consumers. ${ }^{83}$

As explained above, trademark protections are justified as creating incentives for businesses to produce quality goods (by protecting the usurpation of goodwill) and reducing the product search costs of consumers to enabling them to trust marks indicating source and origin. ${ }^{84}$ A key point to observe is that trademark and unfair competition law are essentially dealing with the regulation of communicative behaviors. ${ }^{85}$ Trademark "owners" possess certain rights to seek legal and equitable relief when their competitors engage in acts that create public deception. ${ }^{86}$ The touchstone of trademark and

courts to those parties that can show competitive harms. Halicki v. United Artists Communications, 812 F.2d 1213, 1214 (9th Cir. 1987); see also Conte Bros. Automotive v. Quaker State-Slick 50, Inc., 165 F.3d 221 (3d Cir. 1998).

81 Restatement (ThiRD) OF UNFAir COMPETITION $§ 4$ (1995); see also Dastar, 539 U.S. at $28 \mathrm{n} .1$.

${ }^{82}$ See 15 U.S.C. $\S \S 1117,1125$ (2000).

${ }^{83}$ See id. at $\S 1125$ (setting likelihood of consumer confusion as the standard test for trademark infringement).

${ }^{84}$ See, e.g., Elmer William Hanak III, The Quality Assurance Function of Trademarks, 43 Fordham L. Rev. 363, 364 (1974); William M. Landes \& Richard A. Posner, Trademark Law: An Economic Perspective, 30 J.L. \& Econ. 265 (1987); David G. Post, Pooling Intellectual Capital: Thoughts on Anonymity, Pseudonymity, and Limited Liability in Cyberspace, 1996 U. ChI. LegAL F. 139, 160.

85 See Ringling Bros.-Barnum \& Bailey Combined Shows, Inc. v. Utah Div. of Travel Dev., 170 F.3d 449, 459 (4th Cir. 1999) (rejecting the notion of trademarks as "property rights in gross"). Trademark are, however, commonly described as property interests of the intellectual variety. See, e.g., Michael Carrier, Cabining Intellectual Property Through a Property Paradigm, 54 DUKE L.J. 1 (2004) (exploring the equation of intellectual property with the legal definition of property); Dan Hunter, Cyberspace as Place and the Tragedy of the Digital Anticommons, 91 CAL. L. REV. 439 (2003) (exploring the intersection of property concepts and information); Melissa B. Jacoby \& Diane Leenheer Zimmerman, Foreclosing on Fame: Exploring the Uncharted Boundaries of the Right of Publicity, 77 N.Y.U. L. REV. 1322, 1344-45 \& n.138 (noting that trademarks constitute valuable assets in bankruptcy proceedings); Mark A. Lemley, Property, Intellectual Property, and Free Riding, 83 TEX. L. REV. 1031, 1031-32 (suggesting that the equation of property with intellectual property creates misleading connotations).

${ }^{86}$ See Ann Bartow, Likelihood of Confusion, 41 SAN Diego L. Rev. 721, 722 (2004) (asserting that "[c]onfusion among consumers is the grave iniquity against which trademark 
unfair competition law is this presence of consumer confusion and deception. Without a likelihood of consumer confusion, there can be no cause of action for trademark infringement. ${ }^{87}$

Trademarks are pervasive today - packaging and advertising familiarize us with myriads of marks that are understood to indicate origin or sponsorship of the products on which they are affixed. The animating theory of trademark law is that these marks are providing us with some information value. ${ }^{88}$ But the word "Nike" printed on a pair of sneakers clearly says nothing directly about the quality of the sneakers (at least to consumers not versed in mythology). In order for "Nike" to be recognized as a trademark, it must have some information value, and therefore it must have some meaning to consumers. ${ }^{89}$ In other words, it must be recognized not as a word signifying what the word or symbol might ordinarily signify (a Greek goddess of victory, for instance), but instead as a mark denoting something about the origin, sponsorship, or approval of a good. "Apple" printed on a plastic bag containing apples has a non-trademark meaning. "Apple" printed on a computer has a secondary, trademark meaning denoting the source or origin of the computer. Through our commercial and media consumption, we associate certain marks with particular sources of goods and services and also learn about certain relevant qualities of particular objects associated with the marks. ${ }^{90}$ Even if the public does not know what collective, corporate, sociogeographic, or other identity corresponds to a mark, there is a notion that such

laws and jurisprudence are intended to guard”).

8715 U.S.C. §§ 1051-1150 (2000); Moseley v. V Secret Catalogue, Inc., 537 U.S. 418, 428 (2003) (observing that "[trademark law] broadly prohibits uses of trademarks, trade names, and trade dress that are likely to cause confusion about the source of a product or service”). But see Bartow, supra note 86, at 729-38 (criticizing the standard consumer protection rationale offered in support of trademark law).

88 This theory has been criticized. See Bartow, supra note 86, at 737 ("Reflection on the ways in which trademarks are actually deployed and employed by commercial interests makes the assertion that trademarks protect consumers from being confused, mistaken, or deceived in their purchasing decisions almost laughable, and the contention that broadly protecting trademarks permits consumers to rely on trademarks as accurate source indicators is bizarre indeed.”) (citations omitted).

89 This is called "secondary meaning" in trademark law. The term, as others have observed, is an unfortunate bit of legal jargon. "Secondary" meaning is a good way to explain how Apple ${ }^{\mathrm{TM}}$ and Google ${ }^{\mathrm{TM}}$ have second meanings that differ from designations of a fruit and number, but the Nike swoosh, the word "Häagen-Dazs", and many other fanciful trademarks actually have no primary meaning. The word secondary is not important here the particular type of meaning the word has, namely a trademark-type meaning, is important.

90 See Graeme B. Dinwoodie, The Death of Ontology: A Teleological Approach to Trademark Law, 84 IowA L. REV. 613, 614 (1999) (discussing the historic purpose of trademark law as giving meaning to names and symbols, thereby reducing consumer confusion). 
a distinct identity does exist.

When trademark law allows the average consumer to discern that there is some distinction between various things connected via trademarks to three products marked with the words "Coke," "Pepsi," and "Acme Discount Cola," trademark law postulates that society is better off. ${ }^{91}$ (At least, it postulates, the benefit of regulating permissible speech in this way exceeds any costs imposed by the regulation..$^{92}$ ) It would seem that this is correct. ${ }^{93}$ Were every producer entitled to place the label "Pepsi" or "Coke" on any drink produced, it seems logical that this would lead to a sub-optimal state of information affairs, with no particular beverage company having a sufficient incentive to invest in a superior product because all producers would simply adopt the most appealing mark. ${ }^{94}$ Consumers would be subject to deceptive information practices in a world without protected trademarks: inferior producers would freely tag their products with the marks of superior producers. Indeed, this seems to be exactly what happens. If one visits a country where trademark laws are not enforced, one often encounters cheap counterfeits - substandard goods marked with brands that consumers erroneously believe have the same qualities as legitimate goods..$^{95}$

In order to accept that this kind of consumer confusion is harmful, however, we must accept that trademarks generally signify something that is real and relevant to purchasing considerations. So what does the word "Nike" mean to the average consumer when it is affixed to a pair of sneakers? For the typical consumer, it is worth highlighting how very little information the average trademark conveys. In the case of Nike, consumers may have heard some things about the nature, history, geographic location, finances, employment practices, etc., of the business entity associated with the trademark. In most

${ }^{91} I d$. at 636 (describing how trademark law “promotes competitive values”).

92 Id. at 624 (describing trademark law as a balance of rights between producers and consumers).

93 But see Bartow, supra note 86. I agree with Professor Bartow that there is copious information value that trademarks fail to provide and that there is a need for trademark reform in some areas. However, I believe the traditional view that consumers benefit from the regulation of trademarks is generally correct. The theoretical integrity of trademark law relies on the ability of trademarks to benefit consumers - if trademark law were to abandon consumer benefit as a foundation, there could simply be no plausible theoretical foundation for trademark regulation.

94 See William M. Landes \& Richard A. Posner, The Economic Structure of Intellectual Property Law 270 (2003); see also Stacey L. Dogan \& Mark A. Lemley, Trademarks and Consumer Search Costs on the Internet, 41 Hous. L. REV. 777, 787 n.29 (2004) (explaining that, without trademark law, free-riding would destroy any incentive to invest in a brand).

95 Sandy Meng-Shan Liu, After WTO Accession: China's Dilemma with the Trafficking of Fakes, 93 TRADEMARK REP. 1153, 1157 n.19 (2003) (citing statistics on the amount of counterfeit goods sold in China and describing consumers' disappointment in the quality of those goods). 
cases, however, a trademark will denote next to nothing to the average consumer other than its own existence - it is a signifier without much of a signified. ${ }^{96}$

And when we get down to it: what is Coca-Cola ${ }^{\mathrm{TM}}$, or Nike ${ }^{\mathrm{TM}}$, or Ford ${ }^{\mathrm{TM}}$ ? The words lack any clear signification. When used to refer to companies, the words point to multinational Byzantine structures involving geographically dispersed mazes of subsidiaries, parents, and affiliate entities with overlapping boards. For instance, if Hewlett-Packard were to have sold computers marked with the word "Compaq" in 1998, this would have unquestionably amounted to trademark infringement under the classic A sues B model. Today, however, because $\mathrm{A}$ is $\mathrm{B}$ in that particular situation, the two formerly distinct marks are policed by an integrated entity. ${ }^{97}$ The oddness here is not unusual. Some trademark-holding companies such as Coca-Cola ${ }^{\mathrm{TM}}$ don't really produce anything, but simply license their mark to other producers. ${ }^{98}$ Multiple trademarks are often owned and used by a single enterprise that builds separate brands in order to possess different shares of the market.

Well-known trademarks are often substantially unhinged from any associations with any particular things that consumers might know. Some have taken this absence of clear significance as a reason for questioning why we protect legal interests in trademarks. ${ }^{99}$ I generally think that protection is sound, but clearly there is substantial complexity in claiming that trademarks provide the public with socially useful information. We should say instead that the Coca-Cola ${ }^{\mathrm{TM}}$ mark on a product, for instance, tells us something primarily of legal significance. The mark speaks of the complex web of private orderings and licensing that allowed it to be placed there. Trademarks are, in practice, almost exclusively signifiers of this type of legal ordering.

I say "almost" for two reasons. First, many trademarks do denote, whether or not the consumer knows it, particular concrete sources and persons that are relatively fixed. This reality should be significant for the way we think of trademark law. Second, even the most amorphous trademarks, those that are licensed, re-transferred, and detached from clear practical significance, are not completely unhinged as a legal matter from bearing significance about the nature of the sold object bearing the mark. For instance, Nike could not simply transfer its trademark to another company that would immediately sell inferior

96 The terms "signified" and "signifier" are used to distinguish the formal sign from the sign's social meaning. For an excellent overview of semiotics and thoughts on its application to trademark law, see Beebe, supra note 22, at 623-24.

97 Michael Kanellos \& Ian Fried, HP to buy Compaq for \$25 billion, CNet News.COM, Sept. 3, 2001, http://news.com.com/HP+to+buy+Compaq+for+\$25+billion/2100-1001_3272519.html.

98 See Hughes, supra note 18 (noting how Sara Lee also licenses its trademark to other dessert producers).

99 See, e.g., Rosemary CoOmbe, The Cultural Life of Intellectual Properties 1-6 (1998) (examining the cultural reappropriation of trademarks); Bartow, supra note 86. 
shoes and brand them with the Nike ${ }^{\mathrm{TM}}$ mark, despite the fact that legal documents could easily be drawn that would purport to have that effect. An attempted sale of a trademark interest to a business without similar goodwill constitutes an abandonment of the mark. ${ }^{100}$ Professor McCarthy explains:

Use of the mark by the assignee in connection with a different good will and different product would result in a fraud on the purchasing public, who reasonably assume that the mark signifies the same things, whether used by one person or another. The law's requirement that good will always go with the trademark is a way of insuring that the assignee's use of the mark will not be deceptive, and will not break the continuity of the thing symbolized by the assigned mark. ${ }^{101}$

So, according to the case law on abandonment, as summarized by Professor McCarthy, trademark law is not a willy-nilly legal structuring of licenses for signifier uses. Other doctrine and statutory provisions in trademark law support this notion. Trademarks, in theory, should point to some substantive "thing symbolized by the assigned mark."

Another indicator of the existence of a meaningful signified is the viability of claims of "reverse passing off." Reverse passing off is essentially the same situation described in Figure 1 above. A product made by " $\mathrm{B}$ " is deceptively marked " $\mathrm{A}$ " and sold to the public. The only difference in "reverse passing off," as opposed to "passing off," is that it is B, not A, that brings the action for trademark infringement. ${ }^{102}$ One might ask where the social harm accrues in instances of reverse passing off. After all, there is no requirement for the cause of action that $\mathrm{A}$ acquired the product of $\mathrm{B}$ through improper means. Given that A has possession of the good, if the marks $A^{\mathrm{TM}}$ and $\mathrm{B}^{\mathrm{TM}}$ were devoid of legal meaning, where would be the harm if A marked goods that it rightfully owns with its own separate mark of "source"? Isn't A then the source of the product? For all we know, B might decide to license A to sell B's goods under the $\mathrm{A}^{\mathrm{TM}}$ mark even though $\mathrm{A}$ did not produce the good - thus turning a potential reverse passing off claim into a non-objectionable licensing arrangement. ${ }^{103}$ Indeed, if A's mark is Coca-Cola ${ }^{\mathrm{TM}}$ or Sara Lee ${ }^{\mathrm{TM}}$, this is essentially what happens, with $B$ essentially paying $A$ for the privilege of using $\mathrm{A}^{\mathrm{TM}}$ and A contractually subjecting $B$ to certain standards of product quality. ${ }^{104}$

But where such a licensing arrangement does not exist, and where A has removed or obscured B's mark and replaced it with $\mathrm{A}^{\mathrm{TM}}$, the law for some

100 J. Thomas McCarthy, 2 McCarthy ON TRAdEMARKS AND UNFAir COMPETITION $\S$ 18:2, at 18-6 (4th ed. 1999 \& Supp. 2005).

${ }^{101}$ Id. (emphasis added); Fair Undercar Care, Inc. v. Wakefield, , at *16 (N.D. Ill. July 2, 1992) (quoting MCCARTHY).

102 Restatement (ThiRd) OF UnFair COMPETITION $§ 5$ (1995).

103 Cross, supra note 20, at 730 (explaining that a producer cannot sue for reverse passing off if the producer consented to the rebranding).

104 See The Coca-Cola Company, http://www.coca-cola.com (last viewed August 9, 2005) (stating that the company's syrup is sold by local distribution companies worldwide). 
reason finds a cause of action. ${ }^{105}$ Why? One can explain the claim of reverse passing off by understanding how it presumes the notion that a trademark signifies some thing. The notion must be that $\mathrm{B}$ is the true producer of the good and that the accurate designation of B's mark has greater positive value to society than the use of A's mark. ${ }^{106}$ B's actual production of the object, in the absence of a licensing arrangement with $\mathrm{A}$, gives $\mathrm{B}$ the right to designate its production with its own mark - B's claim of attribution is more true because $\mathrm{B}$ is the actual producer of the product. Thus, A's act of replacing $\mathrm{B}^{\mathrm{TM}}$ with $\mathrm{A}^{\mathrm{TM}}$ is deceptive to society (at least more deceptive than B's intended marking) because A did not actually produce the product. ${ }^{107}$ Again, this provides evidence of the promotion of truth as a goal of trademark law.

\section{Authorship as Trademark}

If one were, simply as a thought experiment, to equate authorial attributions with trademarks and works of authorship with all other goods, misattribution would capture a situation that seems generally analogous to trademark infringement. ${ }^{108}$ Looking again at Figure 1, if John Doe ("B”) were to claim his novel was the work of John Grisham ("A"), John Doe would be liable, in this thought experiment, for traditional "passing off." Consumers would be deceived as to the authorship of the work, mistakenly assuming that Grisham wrote the novel written by Doe.

Plagiarism, on the other hand, would be analogous to reverse passing off. 109 If John Grisham ("A") were to sell a novel written by John Doe ("B”) and were to attribute authorship to himself, he would be liable (again - only in the context of this thought experiment) for "reverse passing off."110 From the consumer perspective, as in the standard passing off situations, the result of Grisham's deception would be identical to the result of Doe's deception. Consumers would mistakenly assume that Grisham wrote the novel written by Doe. Because Doe would be the true author, society would be deceived. The only relevant difference in the two fact patterns would be in the identity of the party responsible for the consumer deception.

Importing theories of trademark to the realm of authorship appears facile at first. Just as trademarks familiarize us with words and logos, the packaging and advertising of movies, music, and even learned legal treatises familiarize

\footnotetext{
105 Restatement (ThiRd) OF UnFair Competition $\S 5$ (1995).

106 See Kwall, supra note 5, at 1005 (noting that one court found reverse passing off objectionable because it deceives consumers).

107 See id.

108 See Restatement (THIRD) OF UNFAir COMPETITION $§ 5$ (1995) (defining trademark infringement).

109 See Green, supra note 25, at 203 ("The analogy between reverse palming off and plagiarism should be clear.”).

110 See Restatement (Third) of UnFair COMPETition § 5 (1995) (defining reverse passing off as marking another's goods with one's own trademark).
} 
us with certain words that are the personal names of the authors and artists who created these works. These authorial tags, like trademarks, generally have little initial information value to consumers. Just as there is little or no a priori meaning or value in the connection of the four or five letters comprising "Dell" or "Pepsi" with computers and beverages, there is little value in the association of the strings of letters in "Steven Spielberg," "Marni Nixon," or "John Henry Wigmore" with works of film, music, or legal scholarship. Yet by tasting things marked as Pepsi ${ }^{\mathrm{TM}}$ and encountering the word Pepsi ${ }^{\mathrm{TM}}$ in social communications and the media, we assemble a mental construct of what Pepsi ${ }^{\mathrm{TM}}$ means. The same is true for authors. Regardless of our like or dislike of products marked with "Tom Clancy," most of us have some impression of what the word "Tom Clancy" denotes about the nature of a thing when the word is affixed to a novel. When we select among an array of possible choices in books, movies, and music, we base our decisions as to whether or not to purchase a Tom Clancy novel (at least in part) upon the qualities we have learned to associate with Tom Clancy. ${ }^{111}$ Of course, those selling products are well aware of how we think about our purchases, and they know how particular authorial attributions, like particular trademark designations, can be used to sell music, books, and movies. ${ }^{112}$

The value of trademarks for cars, computers, and sneakers can wax and wane as brand reputations for quality and prestige fluctuate. Similarly, various author tags wax and wane in value over time, as a result of changing authorial outputs and shifting tastes. In 2004, Dan Brown was a "hot" author, just as the Apple iPod was a "hot" consumer gadget. When deciding whether or not to purchase the latest Steven King, Tom Clancy, or J.K. Rowling novel, the first question for most purchasers may be whether they (or a trusted friend) deemed recent novels by that author to be quality products. ${ }^{113}$ The same is true for goods marked with trademarks.

3. Authorship vs. Trademark

My argument thus far may suggest that we can and should equate author names with traditional trademarks. Yet we can't and we shouldn't. Author names are not the same thing as "Nike" and "Coca-Cola". It is true that

111 See Pinover, supra note 40, at 38 ("Publishers, record companies, movie companies and the entertainment industry count on known names to sell their products, just as trademarks sell soap and cereal.”); see also Dastar Corp. v. Twentieth Century Fox Film Corp., 539 U.S. 23, 33 (2003) (commenting that purchasers of novels are probably interested "primarily[] in the identity of the creator of the story").

112 See Randolph Stuart Sergent, Building Reputational Capital: The Right of Attribution Under Section 43 of the Lanham Act, 19 COLUM. J.L. \& ARTS 45 (1995).

113 Karen L. Gulick, Creative Control, Attribution and the Need for Disclosure: A Study of Incentives in the Motion Picture Industry, 27 ConN. L. REv. 53, 97 (1994) ("[W]hen purchasing one-time experience goods, consumers frequently rely on the advice of family, friends, and occasionally, consumer magazines.”). 
personal names do transform into legally protected trademarks frequently. Some of the oldest and most famous trademarks originated with personal names, such as Disney ${ }^{\mathrm{TM}}$, Ford ${ }^{\mathrm{TM}}$, McDonald's ${ }^{\mathrm{TM}}$, DuPont ${ }^{\mathrm{TM}}$, Tiffany ${ }^{\mathrm{TM}}$, Calvin Klein ${ }^{\mathrm{TM}}$, Johnson \& Johnson ${ }^{\mathrm{TM}}$, Macy's ${ }^{\mathrm{TM}}$, etc. Yet when we buy products marked with Ford ${ }^{\mathrm{TM}}$ and Disney ${ }^{\mathrm{TM}}$, we are not buying the authors Walt Disney and Henry Ford. We may no longer even make the mental association between the trademarks and the personal names that were their source. Whereas personal names are used to identify persons, trademarks are commercial marks used to identify the origins of goods or services.

If we were to equate names with trademarks, one problem would be that most personal names are not unique. Common first names (like James, Michael, or John) tend to be preferred for children. ${ }^{114}$ Surnames are rarely original. Many parents conjoin a traditional name with a common surname and children are given names that are already in current use. If we were talking of trademarks, this kind of widespread use of identical marks would be verboten. In the context of personal names, identical names may cause confusion, yet it seems entirely appropriate that parents should have the freedom to name their children as they please without having to deal with the Patent and Trademark Office. If your surname is Ford and you have named your son Henry (a traditional name), it seems appropriate that this "new" Henry Ford should be free to denote his authorship of his school writing assignments without a license from a certain car company.

However, if young Henry Ford wants to use his personal name to sell automotive goods and services, trademark law will likely interfere. If prior entrants have already established public reputations associated with marks that are personal names, subsequent entrants attempting to use the same names may be barred from utilizing their personal names in association with the sale of goods in related markets. ${ }^{115}$ The law does recognize that there is something vaguely unfair about this to the "new" Henry Ford that just wants to use his name to sell his automotive parts. ${ }^{116}$ Judicial opinions sometimes express the view that people should have an assumed right to use their own names in relation with business ventures if these efforts are made in good faith and without improper motives - even if some degree of consumer confusion results

1141990 Census Bureau data indicates that over ten percent of males are named either James, John, Robert, or Michael. See Frequently OcCURRING FIRST NAMES AND SURNAMES FROM THE 1990 CENSUS, U.S. CENSUS BuREAU, http://www.census.gov/genealogy/names (last modified Mar. 31, 2005). Female name choices typically demonstrate a bit more flexibility. See id.

115 See Quentin R. Wittrock, Note, Use of Personal Names in Noncompeting Businesses - Doctrines of Unfair Competition, Trademark Infringement, and Dilution, 70 IowA L. REv. 995, 997 (1985) (concluding that current law may prevent a local business from using the same trademark as a business that operates nationally, even if the local trademark is the business owner's name).

116 See id. 
from the use. ${ }^{117}$ Courts will therefore bend the strict rules of trademark to give some breathing room to business owners with personal names that might otherwise infringe trademarks. However, you have no absolute right to use your personal name in relation with your business. ${ }^{118}$

Perhaps this impediment to personal name use is ameliorated by the fact that birth names are often fairly dull trademarks and one does not have to choose a trademark for a business or product that is identical to one's personal name. And perhaps it is also ameliorated by the fact that that the marks we associate with our persons are flexible, from both a legal and social perspective. Authors and celebrities have regularly refashioned their identifying signs in order to facilitate self-marketing. Marion Morrison changed his name to John Wayne and Prince Rogers Nelson (who was formerly known as "Prince") changed his name to a symbol defying conventional articulation - reportedly in order to escape certain contractual restrictions. ${ }^{119}$ Skimming a random sample of such substitutions reveals the unsurprising fact that when authors and celebrities adopt new symbols to identify themselves, they pick better trademarks: shorter, more memorable names with more appealing connotations. ${ }^{120}$ It is probably also worth noting that this has often entailed the

117 Id.

118 Id.

119 Though the symbol defies articulation, it has the benefit of being registered as a trademark and also subject to copyright protection, unlike the vast majority of personal names. Judge Posner explained:

The defendant, identified only as 'Prince' in the caption of the various pleadings, is a well-known popular singer whose name at birth was Prince Rogers Nelson, but who for many years performed under the name Prince and since 1992 has referred to himself by an unpronounceable symbol reproduced as Figure 1 at the end of this opinion. The symbol is his trademark but it is also a copyrighted work of visual art that licensees of Prince have embodied in various forms, including jewelry, clothing, and musical instruments.

Pickett v. Prince, 207 F.3d 402, 403 (7th Cir. 2000) (parenthetical comments omitted).

${ }^{120}$ Fabricated monikers include Woody Allen (Allen Konigsberg), Alan Alda (Alphonso D’Abruzzo), Anne Bancroft (Anna Maria Italiano), Pat Benatar (Patricia Andrejewski), Jack Benny (Benjamin Kubelsky), Mel Brooks (Melvin Kaminsky), George Burns (Nathan Birnbaum), Tom Cruise (Thomas Mapother IV), Tony Curtis (Bernard Schwartz), Kirk Douglas (Issur Danielovitch), Bob Dylan (Robert Zimmerman), Cary Grant (Archibald Leach), Elton John (Reg Dwight), Karl Malden (Mladen Sekulovich), Barry Manilow (Barry Alan Pincus), Ricky Martin (Enrique Martin Morales), Walter Matthau (Walter Matuschanskayasky), Chuck Norris (Carlos Ray), George Orwell (Eric Blair), Jack Palance (Walter Palanuik), Martin Sheen (Ramon Estevez), Ringo Starr (Richard Starkey), Sting (Gordon Sumner), and Mark Twain (Samuel Clemens). For more examples, see Nom de Guerre, http://go.to/realnames (last visited Sept. 16, 2005). Such monikers are not always voluntarily adopted. Some performers have been pressured to use stage names. This was allegedly the case with John Mellencamp (né John Mellencamp, but previously called Johnny Cougar, John Cougar, and John Cougar Mellencamp). See Wikipedia: John Cougar Mellencamp, http://en.wikipedia.org/wiki/John_Cougar_Mellencamp (last visited Aug. 7, 
abandonment of names that signify association with an ethnic minority. ${ }^{121}$

The freedom to refashion a personal name is not unlimited or without some downside. While businesses may routinely invent new marks for themselves and their new products and services, prior personal names are more difficult to abandon. Abandoning a name entails a significant social network cost, as all spouses who have adopted new surnames after marriage know. ${ }^{122}$ And modification is not always effective where the public has grown accustomed to a prior signifier: Prince Nelson is still called Prince. ${ }^{123}$ Yet the flexibility to rename oneself is still employed for various purposes. Female authors often employ pseudonyms in order to mask their gender, ${ }^{124}$ and it is not uncommon for authors to employ pen names for particular purposes, such as to write anonymously or in a form or genre with which they are not traditionally associated. ${ }^{125}$

The use of a personal name in relation to the sale of creative works of authorship, therefore, raises some interesting questions for trademark law. It would seem wise to avoid any simple equation of an author's name with a trademark interest - especially if we want to allow later authors who share the personal names of prior authors to use their given names. ${ }^{126}$ Additionally, the requirement of secondary meaning is somewhat problematic. Personal names invariably speak to consumers of a personal identity. Whereas trademarks are inherently commercial and are theoretically associated with the qualities of

2005). Not all celebrities take or are forced to take this course - for instance, Madonna and Britney Spears are well known for the hyper-fabrication of their popular images, but have retained their birth names: Madonna Louise Ciccone and Britney Jean Spears, respectively.

121 See Nom de Guerre, supra note 120.

122 And of course this can, in some cases, be a choice of both spouses. See Eric Schlacter Changes Name to Eric Goldman, Eric Goldman Homepage, Dec. 24, 1997, http://eric_goldman.tripod.com/personal/namechange.htm.

123 See supra note 119. Any unilateral demand that a functioning signifier should be replaced with a new one pointing to an identical signified runs the risk of being ignored or creating some social problems. An interesting example was when, in 1966, the Chinese government tried to replace the standard traffic light "Red=Stop, Green=Go" signification with a new pro-Communist "Red=Go, Green=Stop" signification. After numerous accidents, the attempt was abandoned. See Nicholas D. Kristof, China WaKes: The STRUgGle FOR THE SOUL OF A RISING POWER 70 (1994).

${ }^{124}$ Male author names, like non-minority celebrity names, are generally deemed to be more marketable, especially in genres where male adolescents may be purchasers. See Saul Levmore, The Anonymity Tool, 144 U. PA. L. REV. 2191, 2210-11 (1996) (discussing “crosspenning”). While some female authors employ male pseudonyms, others simply mask their gender identity by using initials rather than their first names. See id.

125 See id. at 2207-15 (discussing pseudonymity). Professor Laura Heymann makes the observation that these "authornyms" share many of the qualities of trademarks. Heymann, supra note 17 , at 1378 .

126 See Wittrock, supra note 115 (discussing when personal names may be used as trademarks despite their lack of uniqueness). 
goods, ${ }^{127}$ personal identities are neither of these things. Yet it is clear that names of authors can and do acquire the same type of commercial significance and secondary meaning that we associate with marks. Famous authors demonstrate that the personal name of an author or artist can accumulate the goodwill and selling power that is associated with a trademark. Pseudonyms and stage names demonstrate that personal names as signifiers can be made flexible and optimized for selling power, just as trademarks are. ${ }^{128}$ In terms of the power of names to denote a real and meaningful signified that has information value to the public, personal names are arguably superior to trademarks because they point to actual persons. Thus, one might argue that they are more deserving of legal, trademark-type protections. Confronted by the strong reasons for recognizing some trademark-like interest in a personal name, courts historically allowed creative authors to pursue trademark-like actions where their names function much like unregistered trademarks. ${ }^{129}$

Where the marketing of a work created consumer confusion as to the authorial "source" of a work, trademark law provided a legal mechanism for authors to bring claims based upon the misattribution of their creative efforts. There are many examples, but a well-known case in this vein is Follett $v$. New American Library. ${ }^{130}$ A publishing company, William Collins Sons \& Company Ltd., had employed (then relatively unknown) author and journalist Ken Follett to make editorial revisions to a book named The Heist of the

\footnotetext{
127 See Restatement (ThiRd) of UnFair Competition § 4 (1995).

128 See supra note 120.

129 Because personal names were rarely registered as trademarks, courts generally
} applied Section 43(a) of the Lanham Act, (codified at 15 U.S.C. § 1125(a)(1) (2000)), which states, in relevant part:

Any person who, on or in connection with any goods or services ... uses in commerce any word, term, name, symbol, or device... or any false designation of origin ... which ... is likely to cause confusion, or to cause mistake, or to deceive ... as to the origin, sponsorship, or approval of his or her goods ... shall be liable in a civil action by any person who believes that he or she is or is likely to be damaged by such act.

See also Pinover, supra note 40, at 40 ("Although artistic identity may not be thought of as a traditional trademark, it should not be surprising that Section 43(a) provides artists and authors protection for the proper attribution of their products. The trademarks or identifications of source are their names.”); id. at 43-44 (discussing Follett v. Arbor House Publishing, 1980 US Dist. LEXIS 13287 (S.D.N.Y. Aug. 28, 1980)); id. at 44-45 (discussing Geisel v. Poytner Products, Inc., 283 F. Supp. 261 (S.D.N.Y. 1968)); id. at 4546 (discussing Lamonthe v. Atlantic Recording Corp., 847 F.2d 1043 (9th Cir. 1988)); id. at 46-48 \& n.30-35 (discussing other cases involving claims of artistic misattribution under the Lanham Act); Gulick, supra note 113, at 112-13 (recounting cases where the Lanham Act was used successfully to prevent instances of misattribution); Natalie C. Suhl, Note, Moral Rights Protection in the United States Under the Berne Convention: A Fictional Work?, 12 Fordham Intell. Prop. Media \& ENT. L.J. 1203, 1218 (2002) ("Courts often interpret the prohibition against 'reverse passing off' in 43(a) as providing authors with a legitimate right to seek proper credit for their work.”).

130497 F. Supp. 304 (S.D.N.Y. 1980). 
Century. ${ }^{131}$ The book described a factual event: a bank robbery and subsequent trial. Three anonymous French journalists had collaborated in writing the book. It was to be published under the joint pseudonym "Rene Louis Maurice."132 Follett made extensive revisions to the original work. ${ }^{133}$ As a result of his editorial modifications, he requested a byline on the title and some copyright interest in the revised works. The copyright request was denied, but it was agreed that the novel would attributed to "Rene Louis Maurice with Ken Follett.” The book was published in England in 1978 with "Rene Louis Maurice" alone listed on the cover, and "with Ken Follett" included on the title page. The book failed to find a publisher in America. ${ }^{134}$

Subsequently, Ken Follett published Eye of the Needle, which became a best seller in the United States. ${ }^{135}$ As Follett's fame grew, an American publishing company, Arbor House, contracted with the owners of the copyright in The Heist of the Century to republish the book under the title The Gentlemen of 16 July. The jacket cover that was planned read: "by the author of TRIPLE and EYE OF THE NEEDLE: KEN FOLLETT with Rene Louis Maurice.”136 It was planned that Follett's name would be the only name on the spine of the book and would appear in letters roughly twice the size of the French authors' pseudonym on the cover. Follett learned of the plan and brought suit.

After dispensing with claims based on copyright and the New York state publicity laws, the court arrived at what it perceived to be the heart of the case. "The key issue, then, is whether the designation of authorship which Arbor House proposes to utilize on the cover of The Gentlemen of 16 July constitutes a violation of section 43(a) of the Lanham Act ...."137 The court concluded that

although Follett's revisions may have been more substantial than those which an editor would ordinarily perform ... it is misleading to depict him as the principal author of The Gentlemen of 16 July. His contributions display none of the special creative attributes which are associated with authorship. Thus, the representation that Follett is the principal author of the book is literally false.... The Lanham Act ... is designed ... to protect the public and the artist from misrepresentations

131 Id. at 306.

132 Id. at 305

133 Id. at 306.

${ }^{134} \mathrm{Id}$.

135 Ken Follett, Eye of THE NeEdLe (1978). Eye of the Needle was actually a republication of his novel Storm Island, which had already been printed in England in 1977. Ken Follett Library: Eye of the Needle, http://www.ken-follett.com/bibliography/eye.html (last visited Sept. 16, 2005).

136 Follett, 497 F. Supp. at 308.

137 Id. at $312-13$. 
of the artist's contribution to a finished work. ${ }^{138}$

Follett succeeded in invoking the Lanham Act to enjoin the publication of the book with the proposed misleading designation of authorship. ${ }^{139}$ It should be noted that none of the cases like Follett that applied the Lanham Act to claims of authorial misattribution were capable of articulating a coherent theory of exactly what authorship was and how it intersected with the protections granted by trademark law. Indeed, the court in the Follett case declared at one point in the opinion that matters of authorship were difficult to theorize:

The concept of authorship is elusive and inexact. Although I do not presuppose to offer a definitive analysis of qualities which give rise to authorship, some such definition is essential to a resolution of the issue before the court. The parties have cited no cases in which the concept of authorship has been carefully dissected, and this court has discovered none. ${ }^{140}$

Yet despite this admission, the court did not shy away from the issue, but instead sallied forth into the difficult task of ascertaining the truth of claims about authorship. Follett and similar cases were united by a common belief that designations of authorship, like trademarks, could be determined to be true or false designations, could mislead consumers as to salient qualities of goods, and that protection under trademark law was thus required. ${ }^{141}$ However, all those cases are no longer reliable precedent after the Supreme Court's recent holding in Dastar Corp. v. Twentieth Century Fox Film Corp. ${ }^{142}$ which I will turn to next.

\section{B. The Dastar Decision}

The Supreme Court's most prominent intellectual property decision in the 2003 term was undoubtedly Eldred v. Ashcroft, ${ }^{143}$ decided in January. In Eldred, a seven Justice majority of the Court upheld a Congressional extension of copyright terms by twenty years in the face of a constitutional challenge. ${ }^{144}$ Turning to trademark law in March, the Supreme Court issued Moseley v. V Secret Catalogue, Inc., ${ }^{145}$ which, as a practical matter, severely limited the

138 Id.

139 Id. at 313.

${ }^{140} \mathrm{Id}$. at 312.

${ }^{141}$ King v. Innovation Books, 976 F.2d 824, 831 (2d Cir. 1992) (locating the harm of misattribution in consumer deception); Geisel v. Poytner Prods, Inc., 295 F. Supp. 331, 34853 (S.D.N.Y. 1969) (discussing whether any injury to the plaintiff or public deception occurred in the copyright context).

142539 U.S. 23 (2003).

143 Eldred v. Ashcroft, 537 U.S. 186 (2003).

144 Id.

145537 U.S. 418 (2003). 
power of the poorly worded and controversial 1995 Federal Trademark Dilution Act. ${ }^{146}$ In June, the Supreme Court trimmed back trademark law yet when it decided Dastar.

The factual background of the Dastar case is complex. In 1948, shortly after the end of World War II (and shortly before Eisenhower's successful presidential campaign in 1952), Doubleday \& Company published Dwight D. Eisenhower's "personal account of World War II," entitled Crusade in Europe $^{147}$ The attribution of authorship to Eisenhower was clearly an intended selling point for the book, just as the attribution to Follett was intended as a selling point of The Gentlemen of 16 July. The front of the dust jacket was taken up with a portrait of a serene and smiling Eisenhower in military uniform against a blank background. The back inside dust cover bore a ringing endorsement from Allan Nevins, described as an "eminent historian." Nevins informed the reader that one of the chief merits of the book was the identity of the author:

Above all, [the book] expresses the personality of the author. Readers will feel this is General Eisenhower speaking. That fact, indeed, is one of the chief merits of the work. It has an air of genuineness, a ring of sincerity; the tone is that of a leader, a serene, highly sagacious leader pouring out his special knowledge with the heartiest desire to tell the truth about himself and others. ${ }^{148}$

Crusade in Europe sold very well - it was even a Book-of-the-Month Club ${ }^{\circledR}$ selection - and this created a demand for a video adaptation. Doubleday licensed exclusive television rights to an affiliate of Twentieth Century Fox so that a television series could be produced. ${ }^{149}$ Fox contracted with Time, Inc. for the production, and the television series produced in 1949 was also called Crusade in Europe. ${ }^{150}$ Time then assigned its copyright in the television series back to Twentieth Century Fox. Doubleday renewed its copyright in the book in 1975 . Fox, however, failed to renew the copyright in the video footage in a timely manner. ${ }^{151}$ Thus, while the copyright in the book continued, the copyright in the video expired in 1977. ${ }^{152}$ Crusade in Europe

146 See 15 U.S.C. $\S 1125$ (2000). The Supreme Court's requirement of a showing of "actual injury" to bring a cause of action for trademark dilution effectively checked the expansion of the dilution remedy into a broader property right. See Moseley v. V Secret Catalogue, Inc., 537 U.S. 418 (2003). Trademark dilution has always been a controversial doctrine and, as Professor McCarthy has noted, is often misinterpreted by district courts. 3 MCCARTHY § 24, supra note 100 , at 24-108 to 24-112.

147 Id. at 25-26.

148 Dwight D. Eisenhower, Crusade in Europe (1948) (dust jacket) (on file with author).

149 Dastar, 539 U.S. at 25-26.

150 Id. at 26.

151 Id. at 23.

152 Id. 
(the video) entered the public domain, that realm of information matter in which no copyright subsists. ${ }^{153}$

At the end of the twentieth century, there was a renewed interested in World War II accompanying the fiftieth anniversary of many of the war's events. The blockbuster film Saving Private Ryan was released along with a slew of other entertainment products. Dastar, a small Oregon corporation, saw an interesting opportunity in the public domain video footage of Crusade in Europe. It took the original footage (obtained from original copies), re-edited that footage slightly, and released it in 1995 as a seven-video set sold under the name World War II Campaigns in Europe. ${ }^{154}$ Dastar must have recognized that the sale of a video that relied heavily on references and passages from a book, Crusade in Europe, would create potential copyright issues. So Dastar removed all video passages making references to the book. Dastar probably also feared that references to the original attributions of authorship to Twentieth Century Fox and Time might create trademark issues - so Dastar deleted the original film credits that appeared within the original video. ${ }^{155}$ The Dastar version of the footage contained a new credit sequence, which was limited to the names of the Dastar editors. Each of the seven Dastar videos began with the words "Dastar Presents . ..."156

Fox, also anticipating the anniversary of the World War, re-acquired the book's video adaptation rights and arranged for the re-release of Crusade in Europe. ${ }^{157}$ Fox did not appreciate the competition from Dastar, which was essentially selling the same Crusade in Europe footage at half the price. Fox brought suit, alleging that by removing the original authorial credits to Twentieth Century Fox, Dastar had engaged in authorial misattribution, implicitly claiming that it had authored the video. ${ }^{158}$ Fox alleged this violated federal trademark law by creating consumer confusion as to the source and origin of the video footage. Doubleday, co-plaintiff, alleged that the copies of the video footage were derivative works that infringed Doubleday's copyright in the original book. . $^{159}$

Both Fox and Doubleday prevailed in the district court. Fox's victory was directly attributable to the Ninth Circuit's "bodily appropriation" standard. ${ }^{160}$

153 See Jessica Litman, The Public Domain, 39 EMORY L.J. 965, 967 (1990) (characterizing the public domain as the stock of raw material from which most creative work is derived).

154 WORLD WAR II: CAMPAIGNS IN EUROPE (Dastar 1995).

$155 I d$.

156 Id.

157 Dastar, 539 U.S. at 26.

158 Id. at 27.

159 Id.

160 See Cleary v. News Corp., 30 F.3d 1255, 1261 (9th Cir. 1994) (adopting the bodily appropriation test); Shaw v. Lindheim, 919 F.2d 1353, 1364 (9th Cir. 1990) (explaining the scope of the Lanham Act). 
The standard was addressed particularly to the situation where trademark law was applied to claims involving the authorship of materials protected by copyright. A similar (slightly more expansive) standard was being used in the Second Circuit. ${ }^{161}$ Essentially, both the Ninth Circuit's "bodily appropriation" and the Second Circuit's "substantial similarity" tests merged elements of copyright and trademark law by allowing a presumption of consumer confusion under trademark law where a substantial portion of a creative work of authorship was misattributed. Thus, an evidentiary showing of copyrightlike similarity between creative works served to trigger a presumption of trademark infringement. The district court in Dastar found, pursuant to the applicable doctrine, Dastar's actions amounted to a willful violation of the federal Lanham Act. ${ }^{162}$ It awarded Fox not only Dastar's profits of $\$ 1,567,213.66$, but also attorney's fees totaling $\$ 1,481,898$. ${ }^{163}$ Doubleday was awarded statutory damages of $\$ 150,000$ for copyright infringement.

On appeal, the Court of Appeals for the Ninth Circuit remanded Doubleday's copyright claim with regard to the book due to a factual question, but affirmed the ruling in Fox's favor with regard to the Lanham Act claim. ${ }^{164}$ The Ninth Circuit decision was unpublished. The Supreme Court's grant of certiorari to Dastar's petition for review was therefore something of a surprise. Amicus parties generally assumed that the Supreme Court took the case in order to strike down the standards in use by the Ninth and Second Circuits. Because the standards were a judicial doctrine that amalgamated the subject matter of copyright and the mechanism of trademark, they did seem prone to legal challenge - clear support for the unique standard could be found in neither body of law. ${ }^{165}$ Thus, a frequent argument in the amicus briefs was that the bodily appropriation standard (and the Dastar decision by extension) was

161 Waldman Publ'g Corp. v. Landoll, Inc., 43 F.3d 775, 783 (2d Cir. 1994); see also Kwall, supra note 5, at 1005 (describing the "bodily appropriation" test and the Second Circuit's substantially similar “substantial similarity” test).

162 Dastar, 539 U.S. at 27-28.

163 Twentieth Century Fox Film Corp. v. Dastar Corp., 2000 U.S. Dist. LEXIS 22064, at *34 (C.D. Cal. Nov. 27, 2000), vacated sub nom. Twentieth Century Fox Film Corp. v. Entm’t Distrib., 2002 U.S. App. LEXIS 7426, at **315-16 (9th Cir. Apr. 19, 2002).

164 The Ninth Circuit found there were triable issues of fact with regard to Doubleday's claims to copyright ownership. Doubleday argued that, under the copyright statute, it was the original "author" of the book because Eisenhower had produced the book as a "work for hire.” Twentieth Century Fox, 2002 U.S. App. LEXIS 7426, at *314; but see id. ("The sale agreement between Eisenhower and Doubleday also gives no indication that the book was a work for hire.”). The work for hire doctrine is discussed briefly in Part III.C. infra.

165 Amicus briefs were filed by several interested parties, many of which made these arguments. See, e.g., Brief of Malla Pollack and Other Law Professors on Question One Supporting Dastar Corp., Dastar, 539 U.S. 23 (No. 02-428); Brief of the American Intellectual Property Law Association in Support of Neither Party, Dastar, 539 U.S. 23 (No. 02-428); Brief of the American Library Association et al., Dastar, 539 U.S. 23 (No. 02428); Brief of the International Trademark Association, Dastar, 539 U.S. 23 (No. 02-428). 
erroneous as a matter of trademark doctrine because it failed to require evidence of consumer confusion. ${ }^{166}$

The Supreme Court ruled in favor of Dastar, as expected.167 However, the Supreme Court's opinion did more than merely negate the aberrant hybrid doctrines. Instead, the Court made a sweeping statement about the scope and nature of trademark law. In language that has been cited by numerous district court opinions in the past two years, the Court stated that the scope of trademark law was limited to the misattribution of "the producer of the tangible product sold in the marketplace."168 The implications of this pronouncement are startling. According to the Court, if Dastar had taken the Fox videotapes, removed an attribution to Fox and resold the tapes with a Dastar label, this type of misattribution would have been actionable pursuant to the Lanham Act as "reverse passing off." 169 However, because Dastar actually produced the physical videotape and only copied the intangible expression, the Court found that Dastar had not violated the Lanham Act by attributing the origin of the videotape to itself. ${ }^{170}$ Query what difference this would actually make to consumers. Yet, bizarre as it may seem, that is what the opinion of the Court says. ${ }^{171}$

Though subsequent district courts have uniformly relied on this "tangible product" language, other interpretations of the case have been proffered in

166 See supra note 165; see also 3 McCARTHY § 24.03[2], supra note 100, at 24-13.

167 Dastar, 539 U.S. at 38.

168 Id. at 31. District court opinions citing this language include Gen. Universal Sys., Inc. v. Lee, 379 F.3d 131, 149 (5th Cir. 2004); Smith v. New Line Cinema, 2004 U.S. Dist. LEXIS 18382, at *9 (S.D.N.Y. Sept. 8, 2004); Schiffer Publ'g, Ltd. v. Chronicle Books, 350 F. Supp. 2d 613, 617 (E.D. Pa. 2004); Larkin Group, Inc. v. Aquatic Design Consultants, Inc., 323 F. Supp. 2d 1121, 1129 (D. Kan. 2004); Bob Creeden \& Assocs. v. Infosoft, Inc., 326 F. Supp. 2d 876, 879 (N.D. Ill. 2004); Tao of Sys. Integration, Inc. v. Analytical Servs. \& Materials, Inc., 299 F. Supp. 2d 565, 572 (E.D. Va. 2004); Carroll v. Kahn, 68 U.S.P.Q.2D (BNA) 1357, at *16 (N.D.N.Y. 2003); Bretford Mfg., Inc. v. Smith Sys. Mfg. Co., 286 F. Supp. 2d 969, 971-72 (N.D. Ill. 2003); Boston Int’l Music, Inc. v. Austin, 2003 U.S. Dist. LEXIS 16240, at *4-5 (D. Mass. Sept. 12, 2003); and Williams v. UMG Recordings, 281 F. Supp. 2d 1177, 1182 (C.D. Cal. 2003).

169 The Court stated that a claim for reverse passing off "would undoubtedly be sustained if Dastar had bought some of New Line's Crusade videotapes and merely repackaged them as its own.” Dastar, 539 U.S. at 31. Oddly, this result was exactly the converse of what Professor John Cross (who joined an amicus brief on behalf of Dastar) had cogently argued was the proper policy direction to take for claims of reverse passing off. See Cross, supra note 20, at 766 ("In conclusion, then, the special characteristics of the artist justify granting a limited cause of action for reverse passing off to artists, but not to others.”); id. at 772 ("The only case in which reverse passing off can be justified is when a work of art, literature, or music is involved.”).

170 Dastar, 539 U.S. at 31-32 (understanding “origin of goods” to refer to the producer of the physical videotape).

171 The opinion spoke for eight Justices. Justice Breyer was recused. Id. 
academic commentary. By far the most common interpretation of Dastar in law review articles and student Notes has been that the case constituted a victory for the public domain. ${ }^{172}$ In other words, because the Supreme Court in Dastar failed to apply trademark law to prohibit the sale materials that had been previously protected by copyright but which had fallen into the public domain, the decision ensured that public domain materials would be maximally free for public use without being encumbered by restrictive intellectual property protections. ${ }^{173}$ Professor Jane Ginsburg has suggested that some members of the Court may have seen Dastar as an act of contrition for Eldred $v$. Ashcroft, a decision that many criticized for failing to vigorously protect the public domain. ${ }^{174}$

Two amicus briefs submitted by groups of law professors in Dastar had

172 See, e.g., Jessica Bohrer, Strengthening the Distinction Between Copyright and Trademark: The Supreme Court Takes a Stand, 2003 Duke L. \& Tech. ReV. 23, 27-28 ("The Court ... was rightfully concerned that allowing the line to blur in a case such as this would create a state of 'perpetual copyright protection' that could nullify the intent and effect of copyright and trademark law."); Hughes, supra note 18, at 32 ("Where Eldred accepted Congress's 20 year extension of copyright - thereby sharply curtailing what will go into the public domain for decades - Dastar shows the Court to be highly protective of the public domain.”); Lynn McLain, Thoughts On Dastar From a Copyright Perspective: A Welcome Step Toward Respite for the Public Domain, 11 U. BAlt. InTELl. Prop. J. 71, 91 (2003) ("It is to be hoped that the Court will continue the work that it has begun. The public domain's borders ... must not be permitted to be truncated by other bodies of law ....”); Kurt M. Saunders, A Crusade in the Public Domain: The Dastar Decision, 30 RuTGERS COMPUTER \& TECH. L.J. 161, 178 (2004) (calling the decision "wise" and stating that "[i]n the end, what Dastar teaches, if nothing else, is that unless a valid intellectual property right, such as a patent or copyright, protects something, it may be freely copied and distributed without attribution”); Richard Ronald, Note, Dastar Corp. v. Twentieth Century Fox Film Corp., 19 Berkeley TeCH. L.J. 243 (2004) ("[T]he Dastar Court frees manufactures [sic] to use public domain works without fear of a burdensome attribution requirement.”); Joshua K. Simko, Comment, "Every Artist Is a Cannibal, Every Poet Is a Thief": Why the Supreme Court Was Right To Reverse the Ninth Circuit In Dastar Corp. v. Twentieth Century Fox Film Corp., 11 J. INTELL. Prop. L. 355, 356 (2004) (arguing that the Supreme Court correctly decided Dastar); Eugene Quinn, Dastar v. Fox: Public Domain Wins in the U.S. Supreme Court, JuRIST (June 4, 2003), (calling the decision "a victory for ... the public domain").

173 With regard to the public domain, see generally James Boyle, The Second Enclosure Movement and the Construction of the Public Domain, 66 LAW \& Contemp. Probs. 33 (2003) (relating the English enclosure movement to intellectual property rights). See also Litman, supra note 153, at 996.

174 Ginsburg, supra note 17, at 267 ("In what some might see as an act of contrition for having upheld copyright term extension in Eldred v. Ashcroft, [Dastar made clear] that a work's entry into the public domain precludes resort to another federal intellectual property statute, the Lanham Trademarks Act, to achieve a de facto prolongation of exclusive copyright-like rights.”). 
argued for reversal primarily based on public domain arguments. ${ }^{175}$ These arguments did appear to have some influence on Justice Scalia's opinion: the Court explicitly stated that creating a right of authorial attribution under trademark law would have the detrimental effect of regulating the free use of public domain materials under a "species of mutant copyright law." 176 The public domain is generally equated with the absence of intellectual property regulations, so there is clearly some truth in seeing Dastar as a victory for the public domain. But in the case of intellectual property laws that prevent consumer deception, the absence of regulation does not always serve the public interest. In any event, the brief nod toward the public domain did not seem to be the driving force behind the Dastar decision. ${ }^{177}$ No subsequent district court decisions have accorded this language much consequence and all courts to consider the issue have been willing to extend Dastar's holding to works not in the public domain. ${ }^{178}$

A second notable view in the scholarly commentary is that the Court's opinion in Dastar rested on an erroneous conclusion of "amateur psychology," namely a faulty empirical belief that consumers didn’t actually care about the

175 Professor Tyler T. Ochoa filed an amicus brief on behalf of himself and other law professors. See Tyler T. Ochoa, Brief Amici Curiae of Intellectual Property Law Professors in Support of Dastar Corporation, 24 WhitTiER L. Rev. 931, 931 (2004). Professor Malla Pollack also submitted a brief on behalf of herself and nine legal scholars. See Pollack, supra note 165 .

176 The full sentence reads:

Assuming for the sake of argument that Dastar's representation of itself as the "[p]roducer" of its videos amounted to a representation that it originated the creative work conveyed by the videos, allowing a cause of action under $\S 43(a)$ for that representation would create a species of mutant copyright law that limits the public's "federal right to "copy and to use,"” expired copyrights.

Dastar, 539 U.S. at 34 (citations omitted and emphasis added). Note that "mutant copyright law" precedes the description of the effects of the putative monstrosity on the public domain. Evidently the "mutant copyright” language was borrowed from the petitioner's brief, which was co-authored by UCLA law professor David Nimmer. See Nimmer, supra note 18, at 60 ("Happily for Justice Scalia (as well as for the U.S. justice system), his own opinion in Dastar eliminates any right to maintain that those words in the Court's opinion represent reverse passing off, thus forestalling my colleagues and me from calling him to the bar!”).

177 But see Ginsburg, supra note 17, at 269 ("Despite this so-far unflinching application of Dastar to still-copyrighted works, one should recognize that the rationale behind the Supreme Court's rejection of attribution rights in copyright-expired works does not extend to copyright-protected works.”); Patchen M. Haggerty, Authors' Claims for Reverse Passing Off Under the Lanham Act after Dastar Corp. v. Twentieth Century Fox Film Corp., FindLAW, Mar. 22, 2004, http://library.findlaw.com/2004/Mar/22/133354.html (“As evidenced by the foregoing analysis of the rationale underlying the Court's Dastar decision, the Court's holding is only meant to preclude a claim for Reverse Passing Off under the Lanham Act for works that are in the public domain.”).

178 See supra note 168 (listing notable cases that have cited to Dastar). 
creative authorship of the products they purchase. ${ }^{179}$ The evidence generally cited is the following statement:

The consumer who buys a branded product does not automatically assume that the brand-name company is the same entity that came up with the idea for the product, or designed the product - and typically does not care whether it is. The words of the Lanham Act should not be stretched to cover matters that are typically of no consequence to purchasers. ${ }^{180}$

This does seem strange. Obviously, from the perspective of those purchasing many works of authorship, this statement is simply wrong. Most fiction consumers do not purchase books based on the identity of the publishing house, they purchase on the basis of, among other things, the author. (Other factors may include the subject matter, the book reviews, and perhaps how pretty the cover is.) The problem with placing too much emphasis on amateur psychology here is that the Court itself acknowledges, in the very next paragraph, that the observation does not hold true in the case of communicative works. The Court's statement about the cares of consumers is probably missing a "generally" - it is true about the consumers of most products protected by trademark law. In the special case of creative works, however, the Court itself stated:

The purchaser of a novel is interested not merely, if at all, in the identity of the producer of the physical tome (the publisher), but also, and indeed primarily, in the identity of the creator of the story it conveys (the author). And the author, of course, has at least as much interest in avoiding passing-off (or reverse passing-off) of his creation as does the publisher. For such a communicative product (the argument goes) "origin of goods" in $\S 43($ a) must be deemed to include not merely the producer of the physical item (the publishing house Farrar, Straus and Giroux, or the video producer Dastar) but also the creator of the content that the physical item conveys (the author Tom Wolfe, or - assertedly respondents).

The problem with this argument according special treatment to communicative products is that it causes the Lanham Act to conflict with the law of copyright, which addresses that subject specifically. ${ }^{181}$

The court further observed that

179 See Graeme B. Dinwoodie, The Seventh Annual Honorable Helen Wilson Nies Memorial Lecture in Intellectual Property Law: The Trademark Jurisprudence of the Rehnquist Court, 8 MARQ. INTELL. Prop. L. Rev. 187, 204 (2004); Hughes, supra note 18, at 33 (observing that Justice Scalia "tells us a strange tale about the psychology of consumers"); Marshall Leafer, Life After Eldred: The Supreme Court and the Future of Copyright, 30 WM. MitCHELL L. REV. 1597, 1614 (2004) ("I am particularly interested in knowing the author's name and I suspect many others hold a similar view.”).

180 Dastar, 539 U.S. at 33.

181 Id. at 33 (emphasis added). 
as used in the Lanham Act, the phrase "origin of goods" is in our view incapable of connoting the person or entity that originated the ideas or communications that 'goods' embody or contain. Such an extension would not only stretch the text, but it would be out of accord with the history and purpose of the Lanham Act and inconsistent with precedent. ${ }^{182}$

Clearly, the Court recognized that consumers often care about authorship, and that the purchaser of a creative artifact may even care primarily about authorship. However, the central holding of Dastar - and the holding understood by district court opinions applying Dastar - is that the "the producer of the physical tome" is permitted to look to trademark law for misattribution protections, whereas "the creator of the story it conveys (the author)" must use copyright law. ${ }^{183}$

A final notable argument found in the secondary commentary is that the Dastar ruling might be limited in scope because claims of "false advertising" might still be used to address authorial misattributions. My first concern with this possibility is that the Court speaks generally, throughout the opinion, of trademark law and the scope of " $\S 43(a)$." False advertising under the Lanham Act is a part of "§ 43(a)." 184 At one point, the opinion does state that a claim under $\S 43(a)(1)(B)$ might be viable under certain circumstances in relation to claims about the content of a communicative product. ${ }^{185}$ But this language deserves careful attention, because it doesn't seem to go far enough to protect against authorial misattribution. The exact situation the Court identifies as actionable under $\S 43(\mathrm{a})(1)(\mathrm{B})$ is a situation where "the producer of a video that substantially copied the Crusade series were, in advertising or promotion, to give purchasers the impression that the video was quite different from that series." 186

This hypothetical situation seems highly unlikely as a practical matter. Why would anyone, especially someone seeking to misattribute authorship, want to claim, in advertising or promotion of the work, that the misattributed work being offered is "quite different" from a prior work that is, in fact, nearly identical? Has there ever been any creative work, in any genre, promoted and advertised as being "quite different" from another particular work that is a nearly identical copy? The Court's hypothetical situation concerns an affirmative claim of "difference" that has little to do with reality. But more important, it has little to do with claims of authorship.

Yet, as stated previously, some very erudite commentators have held out the possibility that the issues presented by Dastar might be resolved by looking to

\footnotetext{
182 Id. at 32 (emphasis added).

183 Id. at 33.

184 See 15 U.S.C. § 1125(a)(1)(B) (2000).

185 Dastar, 539 U.S. at 38.

${ }^{186} I d$.
} 
the niceties of pleading. ${ }^{187}$ Fox should have claimed misattribution under the false advertising provisions of the trademark law, § 43(a)(1)(B), instead of section $\S 43(\mathrm{a})(1)(\mathrm{A})$, which addresses confusion over the origin of goods. While it is possible that some subsequent district court interpreting Dastar might take this approach, it hasn't happened yet. Instead, courts have spoken broadly about § 43(a) and Dastar's tangibility limitations. ${ }^{188}$

187 See Nimmer, supra note 18, at 44 \& n.255 (suggesting that affirmative authorial misattributions are still actionable pursuant to $\S 43(\mathrm{a})(1)(B)$ where the attribution claims made are of consequence to purchasers, and thanking Professor McCarthy for "elucidating this point”). But see Bretford Mfg., Inc. v. Smith Sys. Mfg. Co., 286 F. Supp. 2d 969, 972 (N.D. Ill. 2003) ("As a backup argument, Bretford contends that Smith was guilty of 'false advertising' ... . But Dastar blocks that argument as well.”); 2 MCCARTHY § 10.26.1, supra note 100, at 10-63 (rather carefully stating that after Dastar, "to trigger Lanham Act $\S$ 43(a) claims, false claims of creation of the intellectual property content of a product must fit within the false advertising prong of § 43(a)(1)(B)”); Ginsburg, supra note 17, at 269 ("Whether or not the actor or I can still allege false designation of origin, the Dastar Court's reference to subsisting section 43(a)(1)(B) claims ... may in some instances preserve a Lanham Act right of action for authors and performers.”).

188 See, e.g., Gen. Universal Sys., Inc. v. World Trade Sys., Inc., 379 F.3d 131, 149 (5th Cir. 2004) ("GUS has not accused HAL of taking tangible copies of its software, removing its trademarks, and selling them as its own. Rather, GUS asserts that HAL copied the ideas, concepts, structures, and sequences embodied in its copyrighted work .... Dastar makes clear that such claims are not actionable under § 43(a).”); Bob Creeden \& Assocs. v. Infosoft, Inc., 326 F. Supp. 2d 876, 879-80 (N.D. Ill. 2004) (dismissing a Lanham Act claim based on misattribution of a software program because the system at issue was the allegedly infringing copy of the plaintiff's software system, not the original software itself); Tao of Sys. Integration, Inc. v. Analytical Servs. \& Materials, Inc., 299 F. Supp. 2d 565, 572 (E.D. Va. 2004) (finding that misattributed ideas and concepts in a proposal did not violate the Lanham Act because the allegedly misattributive proposal was physically produced by the defendant); Larkin Group, Inc. v. Aquatic Design Consultants, Inc., 323 F. Supp. 2d 1121, 1126 (D. Kan. 2004) (finding unaccredited copying of proposals was not a violation of the Lanham Act, and commenting that "[e]ven if plaintiff authored some of the ideas and concepts embodied in those proposals, the Lanham Act does not provide protection for such plagiarism”); Smith v. New Line Cinema, 2004 U.S. Dist. LEXIS 18382, at **9-10 (S.D.N.Y. Sept. 8, 2004) (“As the Supreme Court recently made clear, the Lanham Act protects only 'the producer of the tangible goods that are offered for sale, and not ... the author of any idea, concept, or communication embodied in those goods.' ... In light of Dastar, Smith, as the alleged author of the screenplay embodied in the tangible good offered for sale, is not the originator of the film.”) (citations omitted); Schiffer Publ'g, Ltd. v. Chronicle Books, LLC, 2004 U.S. Dist. LEXIS 16180, at*11 (E.D. Pa. August 11, 2004) ("[B]ecause Defendants are the physical producers - the fabricators, so to speak ... they cannot be held liable under $\S$ 43(a)(1)(A) even if they are not the creators of the pictures at issue.”); Carroll v. Kahn, 2003 U.S. Dist. LEXIS 17902, at **16-17 (N.D.N.Y. Oct. 9, 2003) (interpreting reverse passing off under the Lanham Act to be limited to cases involving the tangible goods actually produced by the plaintiff); Boston Int'l Music, Inc. v. Austin, 2003 U.S. Dist. LEXIS 16240, at *4 (D. Mass. Sept. 12, 2003) (finding "reverse passing off" to be limited to cases involving tangible goods and "declin[ing] to construe $\S$ 
This brings us back to the language about tangibility. It is hard to accept that the Supreme Court could have meant to draw such a bright, radical, and theoretically destabilizing line between copyright and trademark, yet subsequent district court opinions suggest that Dastar has removed authorial attribution protections from the scope of trademark law - because authorship is intangible. ${ }^{189}$ Perhaps the better reading of the opinion would be to limit it to cases involving "communicative products." 190 Perhaps the best subset of the possible scope of "tangibility" would be to restrict the limit of Dastar to information products potentially covered by copyright law. If Dastar is, at its core, about placing authorial misattribution concerns in the realm of copyright law (and this seems to be a plausible reading), this approach may be a way of cabining its scope. But if copyright now governs authorial attribution, what does that mean for society? The next section addresses this question.

\section{Misattribution and Copyright}

\section{The [copyright] law was designed as a deterrent to plagiarism. ${ }^{191}$}

According to the Supreme Court's opinion in Dastar, copyright law is the constitutional and statutory vehicle that addresses the attribution of works of creative authorship. ${ }^{192}$ Justice Scalia said that copyright speaks to authorial attribution "specifically." 193 While Justice Scalia was clearly thinking of a

43(a) of the Lanham Act to require attribution to plaintiff [and alleged co-author] Johnson for 'I Like It,' where the defendants here are the 'origin' of the product they recorded, produced, and sold on their own.”); Williams v. UMG Recordings, 2003 U.S. Dist. LEXIS 18400 , at $* 18$ (C.D. Cal. Aug. 11, 2003) ("Plaintiff would have a claim if Defendants purchased copies of Plaintiff's goods (i.e. the film) and repackaged them as their own. By contrast, Plaintiff does not have a claim for his authorship and direction embodied in that film. His claim, therefore, is barred as a matter of law.”).

189 See supra note 188 (listing notable lower court interpretations of Dastar). There are many reasons this distinction makes no sense, but the most obvious is that trademark law regularly protects trademark rights in relation to the provision of services, which may be intangible.

190 But see Bretford Mfg,, 286 F. Supp. 2d at 971-72 (finding that defendant's sale of a table that incorporated a leg from plaintiff's table was not reverse passing off because Dastar's holding was not limited to "communicative products").

191 Sheldon v. Metro-Goldwyn Pictures Corp., 309 U.S. 390, 393 (1940). The language is taken from the syllabus, though the opinion also seems to conflate those who infringe copyrights with plagiarists. Id. at 405 ("Petitioners stress the point that respondents have been found guilty of deliberate plagiarism ....”).

192 Dastar Corp. v. Twentieth Century Fox Film Corp., 539 U.S. 23, 33 (2003) (interpreting U.S. ConsT. art. 1, § 8, cl. 8).

${ }^{193} \mathrm{Id}$. It is clear in the context of the opinion that Justice Scalia was thinking of the Visual Artists Rights Act, codified at 17 U.S.C. § 106A (2000), as the section of the copyright statute that "addresses that subject." As discussed in this section, that Act is a 
narrow provision in the copyright statute - the Visual Artist Rights Act ("VARA") - it might not seem odd for a member of the public to think that copyright would be the proper statutory regime that would address the misattribution of authorship. ${ }^{194}$ After all, copyright law is often associated in the popular mind with prohibiting and policing plagiarism. The writer of the syllabus in Sheldon v. Metro-Goldwyn Pictures Corp., an often-cited Supreme Court copyright opinion from 1940, clearly believed this to be the case. ${ }^{195}$

Yet contrary to the impression one might gain from reading the many judicial opinions that conflate copyright infringement with plagiarism, there is actually no law prohibiting plagiarism and misattribution generally. ${ }^{196}$ While the copyright statute spells out in voluminous (some might say agonizing) detail the specific quasi-proprietary rights related to the performance, reproduction, broadcast, and display of expressions via particular methods and technologies, it almost entirely ignores attribution interests. ${ }^{197}$ Unlike European copyright regimes, which grant "moral rights" to authors, the copyright law of the United States ignores the attribution concerns of authors almost entirely. ${ }^{198}$

\section{The Meaning of VARA}

One significant exception to this is found in the provisions of VARA that Justice Scalia apparently had in mind. VARA is generally recognized as an effort on the part of the United States to come into greater compliance with "moral rights" treaty obligations pursuant to the Berne Convention for the Protection of Literary and Artistic Works. ${ }^{199}$ On March 1, 1989, the United States was required to recognize and implement a legal order where,

small exception to the general rule that copyright does not speak to attribution interests.

194 See Green, supra note 25, at 200 (noting how “copyright infringement is sometimes loosely referred to by courts as 'plagiarism'”).

195 Sheldon, 309 U.S. at 393.

196 Dastar, 539 U.S. at 36 (explaining that the courts have not recognized plagiarism generally as a prohibited act); Green, supra note 25, at 171; Kwall, supra note 5, at 955 (explaining that copyright law does not specifically protect against misattribution); $c f$. Saunders, supra note 172, at 161 (summarizing Dastar as follows: "[t]he Lanham Act does not provide a claim for trademark infringement for what is essentially an act of plagiarism”). Indeed, the absence of a clear remedy for "plagiarism" has been the case for quite a while. See Henry Goudy, Plagiarism: A Fine Art, 20 JuRID. REv. 302, 302 (1909) ("In its modern sense plagiarism cannot be said to be a crime punishable either by English or Scottish law, or, so far as I am aware, by any European code.”).

19717 U.S.C. § 101-106 (2000) (setting forth exclusive rights).

198 See Gulick, supra note 113, at 91-92 (comparing and contrasting European and American approaches to copyright); Neil Netanel, Alienability Restrictions and the Enhancement of Author Autonomy in United States and Continental Copyright Law, 12 CARDOZO ARTS \& ENT. L.J. 1, 2 (1994); Suhl, supra note 129, at 1203-15 (comparing VARA with moral rights protections in European law).

199 See Hughes, supra note 18. 
independently of an author's economic rights, the law would protect an author's "right to claim authorship of the work" and certain other "moral rights." 200 VARA was enacted the subsequent year. ${ }^{201}$ Clearly there is good reason to suspect a causal link here, and the legislative history of VARA fully supports such a connection. ${ }^{202}$ It has been claimed that the enactment of VARA was needed for full compliance with the Berne Convention. ${ }^{203}$ However, it has also been claimed that VARA was narrowly drafted because United States compliance with Berne had been substantially achieved though protections afforded by other regimes of law, most notably the trademark protections that existed prior to Dastar. ${ }^{204}$ The current status of United States compliance with Berne is therefore unclear. ${ }^{205}$

But whatever the reasons for VARA's enactment, VARA protects authorial attribution and "moral rights" only for a very limited set of works: namely, original works by visual artists who produce single works, limited edition prints, or sculptural casting in editions of less than 200.206 As a practical matter, this limitation essentially ensured that VARA would serve to protect the idealized "fine artists" who sell physically original paintings and sculptures in small galleries, but would leave the hugely profitable commercial copyright industries (e.g., publishing, film, music, and software) untouched. ${ }^{207}$ Outside

200 See Berne Convention for the Protection of Literary and Artistic Works, supra note 51 ("Independently of the author's economic rights, and even after the transfer of the said rights, the author shall have the right to claim authorship of the work and to object to any distortion, mutilation or other modification of, or other derogatory action in relation to, the said work, which would be prejudicial to his honor or reputation.”); see generally Hughes, supra note 18.

${ }^{201}$ H.R. Rep. No. 101-514 at 24 (1990) (reporting bill's passage by the Judiciary Committee); Netanel, supra note 198, at 4.

202 See H.R. Rep. No. 101-514 at 7-10 (describing how VARA was prompted by U.S. accession to the Berne Convention).

203 See, e.g., Suhl, supra note 198, at 1215 (summarizing VARA as a United States concession to Berne that "grants a bundle of Moral Rights to a limited group of visual artists”).

204 See Corey Field, Berne Goes to the Movies, Copyright WorLd, July-Aug. 2003, at 23, 24-25.

205 This is an interesting issue that I will leave to others to explore. See id. (noting the potential conflict between the holding in Dastar and the Berne Convention); Hughes, supra note 18.

206 See 17 U.S.C. § 101 (2000) (defining “work of visual art”); 17 U.S.C. § 106A (2000) (providing special protections for such works).

${ }^{207}$ Cross, supra note 20, at 735 ("[VARA] is too narrow to serve as a general source of Reverse Passing Off.”). It should be noted that not all gallery artists are protected. For instance, the works of Thomas Kinkade, "Painter of Light," are reproduced in copious numbers and thus would probably not qualify as being "work[s] of visual art” under the statute despite the fact that they are displayed and sold in galleries. See 17 U.S.C. § 101; The Official Thomas Kinkade Website, http://www.thomaskinkade.com (last visited Aug. 12, 2005). 
the limited context of VARA works, copyright law has not protected attribution interests at all. ${ }^{208}$ Thus, Justice Scalia's statement that § 43(a) of the Lanham Act is incapable of speaking to authorial attribution because copyright "addresses that subject specifically" is a very powerful statement regarding the current status of attribution interests: it suggests that there are virtually no such protections (except for visual artists producing limited edition or unique works) and that this is by design. ${ }^{209}$

However, it is unclear exactly what Justice Scalia was saying when he spoke of the conflict between copyright and trademark. If he was attempting to interpret what Congress had intended when it passed or amended the Lanham Act, it is hard to follow how the Congressional passage of special attribution protections for a discrete subset of original artistic works in 1990 somehow illuminated the intent of Congress in the passage of the original version of $\S$ 43(a) of the Lanham Act in 1946 (or later major amendments to § 43(a) made in 1988). And if the notion was that VARA was intended to clarify the limited federal regulation of authorial attribution (and preempt any other efforts to regulate attribution), the legislative history of VARA makes this a very strange proposition. It has been cogently argued that the legislative history of VARA suggests that the Lanham Act § 43(a) protections were considered important to meeting the country's obligations under the Berne Convention. ${ }^{210}$ The existence of alternative avenues of relief for authors makes a fairly good explanation for the very limited scope of VARA's attribution protections. There doesn't seem to be any support for the contention that Congress enacted VARA with the intent to entirely occupy the field of authorial attribution protections. ${ }^{211}$

\footnotetext{
208 Professor Jane Ginsburg and Justin Hughes have both suggested that the Digital Millennium Copyright Act may also protect attribution interests by outlawing intentional removals of "copyright management information" that is conveyed in connection with the work. See Ginsburg, supra note 17, at 283; Hughes, supra note 18, at 16; see also 17 U.S.C. 1202(c) (2000). This is an interesting observation, but, as of this writing, it has apparently not been utilized or endorsed by a court. See Ginsburg, supra note 17, at 283-86 (failing to cite any cases endorsing this approach).

209 Dastar Corp. v. Twentieth Century Fox Film Corp., 539 U.S. 23, 33 (2003).

210 See Ginsburg, supra note 17, at 281-82 (explaining U.S. obligations under the Berne Convention); Hughes, supra note 18, at 3 (describing the Lanham Act as the "keystone” of U.S. compliance with the Berne Convention).

211 The most plausible (and, at the same time, the most radical) reading of the conflict would be one that did not focus on Congressional intent, but on some form of constitutional preemption instead. The import of this reading, however, would be extremely destabilizing for numerous other areas of law. For instance, it could conceivably affect other noncopyright schemes protecting authorship rights, including state laws concerning misappropriation and rights of publicity. See, e.g., Toney v. L'Oreal, Inc., 406 F.3d 905, 908-09 (7th Cir. 2005) (finding that the Illinois right of publicity statute is not preempted by the Copyright Act based on Congressional intent, but not reaching the constitutional preemption analysis, which might have altered the outcome).
} 


\section{Copyright as Collateral Attribution Protection}

Yet even if copyright doesn't explicitly speak to attribution outside of VARA, does this mean that copyright law does not address attribution? It might be argued that copyright protects attribution in a collateral fashion. By protecting works of creative authorship as property, copyright enables the contractual protection of attribution. If an author can control the dissemination and reproduction of her work pursuant to copyright law, copyright law will grant her the contractual leverage to protect her attribution interests. In fact, this doesn't follow nearly as neatly as one might assume, for two essential reasons. First, if we think attribution should be about providing incentives to authors, the fact is that copyright as property does not always provide any attribution-related incentives to people who we would ordinarily identify as authors. Second, social attribution interests are not necessarily aligned with or served by "attribution rights" that are exclusively granted to authors.

Taking the first issue, the Supreme Court in Dastar seemed to argue that there is an inherent difficulty in fixing credit for authorship. In refusing to hold that an author could be held to be the "origin" of a work under the Lanham Act, Justice Scalia stated:

Without a copyrighted work as the basepoint, the word "origin" has no discernable limits. A video of the MGM film Carmen Jones, after its copyright has expired, would presumably require attribution not just to MGM, but to Oscar Hammerstein II (who wrote the musical on which the film was based), to Georges Bizet (who wrote the opera on which the musical was based), and to Prosper Mérimée (who wrote the novel on which the opera was based). In many cases, figuring out who is in the line of "origin" would be no simple task. ${ }^{212}$

The Court is right that determining authorship is "no simple task." But is this fatal to the project? Copyright law, by granting an initial monopoly reproduction and performance interest exclusively to "authors" who originate creative works has long had to struggle with the difficulty of determining who is an author that originates a work. In cases such as Burrow-Giles Lithographic Co. v. Sarony, ${ }^{213}$ the Supreme Court had to determine who was the "author" of a photograph - the photographer or the subject. This was "no simple task," but it was managed. ${ }^{214}$ The Supreme Court and lower courts

${ }^{212}$ Dastar, 539 U.S. at 35. It is worth noting how closely Scalia's refusal to accept the very concept of original authorship in this passage seems to comport with the abovementioned post-structuralist criticisms of authorship and originality. See, e.g., Boyle, supra note 49, at 642-43 (questioning whether attempts to ascertain the intent of the framers can guide constitutional interpretation in light of post-structuralist critiques). This seems somewhat ironic given Justice Scalia’s well-known hermeneutic inclinations.

213111 U.S. 53 (1884).

${ }^{214} \mathrm{Id}$. at 58-59 (holding that the photographer, not the subject, was the author of a photograph). 
have regularly engaged in non-simple tasks without throwing their hands in the air.

The end result of all this cogitation, however, has not led to anything simple. Instead, the result - predictably - has been to transform what was a vague social concept of authorship into a legal term of art that is governed largely by case law and statutory provisions. The legal definition of "author" has diverged substantially from its popular definition. A legal "author" may, in some cases, be an employer who hires an employee to create a work. ${ }^{215}$ Copyright in such a case protects the employer-author's interest, but not the employee's interest. The definition of "author" is further clouded in the case of collectively authored works. A "joint work" under the copyright statute is "a work prepared by two or more authors with the intention that their contributions be merged into inseparable or interdependent parts of a unitary whole."216 However, because the statute does not define the term "author" in the first place, it is unclear how wide the circle of joint authorship should be drawn in copyright law. In some cases it is drawn, like the work for hire provisions, inconsistently with popular understandings of authorship. ${ }^{217}$

The divergence between legal and popular constructions of the notion of authorship is perhaps best illustrated by the Ninth Circuit case of Aalmuhammed v. Lee.218 In that case, Spike Lee employed Denzel Washington to play the role of Malcolm X in the eponymous film. ${ }^{219}$ Washington turned for advice to Muslim scholar Jefri Aalmuhammed, who eventually (and without a "work for hire" agreement), re-wrote passages of the

21517 U.S.C. § 101 (2000) (setting forth various definitions but failing to define “authors”); cf. 17 U.S.C. $§ 201$ (2000) (stating that an employer can be “considered the author”); Cmty. for Creative Non-Violence v. Reid, 490 U.S. 730, 739 (1989) (defining a "work for hire" in terms of an author's employment status); Erickson v. Trinity Theatre, Inc., 13 F.3d 1061, 1067-69 (7th Cir. 1994); see also 17 U.S.C. \$101 (defining a "joint work”): 17 U.S.C. $\S 201$ (“In the case of a work made for hire, the employer or other person for whom the work was prepared is considered the author for purposes of this title, and, unless the parties have expressly agreed otherwise in a written instrument signed by them, owns all of the rights comprised in the copyright.”).

21617 U.S.C. § 101. Some courts have imposed an additional requirement that the contributions of each "joint author" should be sufficiently original and expressive to be subject to copyright separately. See Childress v. Taylor, 945 F.2d 500, 506-07 (2d Cir. 1991) (discussing cases that explore the concept of a "joint work"); Mary LaFrance, Authorship, Dominance, and the Captive Collaborator: Preserving the Rights of Joint Authors, 50 EMORY L.J. 193, 196 (2001) (presenting alternate tests to determine if a joint work exists).

217 See generally F. Jay Dougherty, Not a Spike Lee Joint? Issues in the Authorship of Motion Pictures Under U.S. Copyright Law, 49 UCLA L. REV. 225 (2001).

218202 F.3d 1227, 1235-36 (9th Cir. 1999) (establishing a narrow definition of "joint work" for motion pictures).

${ }^{219}$ Id. at 1229. 
film script and added new scenes and characters. ${ }^{220}$ Despite Aalmuhammed's clear creative contribution to the collective enterprise of the movie, the Ninth Circuit found that Mr. Aalmuhammed was not an author of the movie, because his role was too indirect to be considered "authorial."221 The court found, instead, that the sole author of the film was the film company, pursuant to work for hire agreements. ${ }^{222}$

Many scholars have expressed discomfort with the result in Aalmuhammed. ${ }^{223}$ For instance, Martha Woodmansee has suggested that the Aalmuhammed case demonstrates the continuing vitality of a "romantic notion of authorship" that ignores collaborative creativity and instead gives legal primacy to a quasi-mythological notion of the artist as a solitary genius. ${ }^{224}$ Many others have criticized the mythology of the "romantic author" as a means to expose what they see as a flawed ideology animating the copyright statute. 225 Whatever one makes of these critiques, the Aalmuhammed case and the work for hire doctrine reveal that the notion of authorship in copyright law and the notion of authorship in popular culture can be incongruent. Copyright law at times seems willing to provide counter-intuitive determinations of who is a legal author, and thus entitled to legal ownership and proprietary control of creative works. If one believes there is a societal interest in accurate attribution, copyright's scheme of authorship ordering is obviously problematic because the legal author controlling attribution is not the person society views as the author. ${ }^{226}$ Jefri Aalmuhammed clearly has no ability at this point, via copyright law, to control how Warner Brothers decides to attribute the scenes he authored (but did not legally author). Even thought he did not contribute to the film under the standard work for hire contract, he was still found to lack a

220 Id. at $1231-32$.

221 The court's reasoning was notably tautological. See id. at 1235 (“Too open a definition of author would compel authors to insulate themselves and maintain ignorance of the contributions others might make.”). In other words, in order to effectively encourage authors to work together, not all authors can be authors.

222 Id. at 1235 ("Warner Brothers required Spike Lee to sign a 'work for hire' agreement, so that even Lee would not be a co-author and co-owner with Warner Brothers.”).

223 See Dougherty, supra note 217, at 325 (discussing the unfairness and possible economic inefficiency of the joint authorship doctrine); Martha Woodmansee, Response to David Nimmer, 38 Hous. L. REv. 231, 234-35 (2001) (critiquing the underlying theory of authorship in the Aalmuhammed case).

${ }^{224} I d$. at 234 (using the case as an example in the course of "defend[ing] the continuing relevance of literary studies in the discourse of copyright”).

225 Theories regarding the intersection of romantic authorship, copyright, and literary theory enjoyed a heyday of sorts in the early 1990s. See generally supra note 60; cf. Jane Ginsburg, Creation and Commercial Value: Copyright Protection of Works of Information, 90 Colum. L. REV. 1865, 1866 (1990) (critiquing various assertions with regard to the rationales animating copyright law).

${ }^{226}$ Gulick, supra note 113, at 66 ("What does it mean to have an author who is not the creator of his work?”). 
proprietary interest in his creative contributions to the film.

\section{The Attribution/Copyright Mismatch}

This is not to say that the Aalmuhammed case reached the wrong result as an issue of social policy. If the case is understood as deciding the proper proprietary control of the copyright in the film Malcolm $X$, it may well reach the right result. There are legitimate reasons, related to economic efficiency, that copyright law might attempt to shift copyright ownership from the hands of a diverse set of contributors (including those like Jefri Aalmuhammed) to single "dominant" employers and authors. ${ }^{227}$ To the extent copyright law evinces a coherent theory, it is best understood in the United States as a system designed for the purpose of maximizing the generation and popular distribution of new works. ${ }^{228}$ It can be argued that shifting ownership of copyright into the hands of an eager and well-financed exploiter that funds production is the best way of ensuring the distribution of the collaborative works to markets. If we see authorship simply as a system for efficiently parceling out proprietary ownership rights, the law should grant ownership (denoting it as "authorship") to the most efficient distributors and exploiters of works. Again, the problem with this model - from the standpoint of attribution - is that the non-statutory, non-dominant author lacks the control to secure attribution.

Even where authors have nominal control over the copyright in their work, the problem of misattribution is not solved. There are several reasons for this. First, authors may suffer from unequal bargaining power vis-à-vis publishers and distributors. Compared to the commercial publishers and exploiters of creative material, aspiring authors are generally impecunious and legally unsophisticated. The established industry players, secure veterans of the process, can generally exert their greater power to obtain written assignments of copyright in exchange for negotiated compensation. After an author alienates the copyright in a creative work, the United States copyright statute generally provides few mechanisms for that author to reclaim control over the exploitation of the work. (VARA is an exception to this rule. ${ }^{229}$ ) Again this accords well with a utilitarian, property-centric view of copyright. By minimizing encumbrances restricting subsequent exploitation, copyright, in

227 But see Dougherty, supra note 217, at 324-25 (arguing that a liability rule would be more efficient than a property rule).

228 Tom W. Bell, Authors' Welfare: Copyright as a Statutory Mechanism for Redistributing Rights, 69 BROOK. L. REV. 229, 238 (2003) (arguing that "copyright aims to alleviate the market's failure to give adequate incentives for producing expressive works"); Green, supra note 25, at 202 (noting that copyright law protects primarily economic interests).

22917 U.S.C. $\S 106 \mathrm{~A}$ (2000). The mechanism of statutory termination rights are another way authors might reclaim proprietary control of their work, but the mechanism only comes into play several decades after the work's creation. See 17 U.S.C. §§ 203, 304(c) (2000) (allowing authors to reclaim rights during certain periods after having sold those rights). 
theory, enables the alienation of a maximum amount of authorial interests in order to maximize authorial incentives. By maximizing the amount of control that authors may transfer, the law maximizes the value of the work that can be transferred for payment. Of course, in cases of unequal bargaining power, and in cases where third parties can suffer from the effects of private transactions, the simple goal of maximizing the power of free markets can be questioned.

A second problem with relying on authors to use copyright to obtain attribution is that a copyright exists only for a limited period. ${ }^{230}$ When copyright lapses, the ability to police against misattribution also fades away. Even assuming Shakespeare once had a copyright that he would have asserted to protect against misattribution, the plagiarism of Shakespeare today would fall outside the scope of attribution protections. From the standpoint of incentives for Shakespeare to produce new works (the concern of copyright), this is just fine. Shakespeare is dead. From the standpoint of the social distribution of his works this is also fine. Fewer restraints will lead to greater distribution. But from the standpoint of consumer protection with regard to misattribution, it is a problem. This concern about the social effects of misleading communication is why trademark interests, unlike copyright interests, have no temporal limitations. ${ }^{231}$

Finally, and perhaps most seriously, policing attribution by using authorial control has a glaring structural defect. Authors often have incentives to misattribute creative authorship, deceiving society as to the authorship of creative work when this deception can provide them with benefits. This possibility will be explored in more detail in Part III.

\section{Misrepresentation and Other Legal Mechanisms}

Of course, even in the absence of copyright and trademark protections, there still exist private causes of action that regulate the use of authorial attributions in ways that contribute to the protection of societal interests. For instance, there are numerous state statutory vehicles that permit actions against parties that engage in commercial fraud or misrepresentation. In the case of consumer purchases of deceptively attributed works of authorship, such claims would hardly be worth the cost of a legal complaint for individual purchasers. If aggregated in a class action vehicle, however, they might have some chance of succeeding. 232

${ }^{230}$ U.S. ConST. art. 1, § 8, cl. 8; Eldred v. Ashcroft, 537 U.S. 186, 192-93 (2003) (citing the Constitution's Copyright Clause in upholding Congress's power to extend the term of copyright).

231 See 3 MCCARTHY § 24.03[2], supra note 100, at 24-13 (describing the purposes of trademark law).

232 The class action vehicle is obviously a whole issue of its own. It is worth noting, though, that in at least one case where a class action strategy was attempted to remedy an authorial misattribution, it proved unsuccessful. For a discussion of the misattributions of authorship engaged in by the band Milli Vanilli, see Freedman v. Arista Records, Inc., 137 
The most obvious possibility, however, is one that has been employed successfully by authors in the past: rights of publicity. ${ }^{233}$ Many state laws recognize a quasi-proprietary right of publicity that permits a cause of action in cases where a party makes an unauthorized use of a person's identity for commercial purposes. ${ }^{234}$ These state rights of publicity could be effective in policing attributional concerns. ${ }^{235}$ Where Party A claims that a seller has "passed off" a creative work by claiming that it was authored by A, when it was in fact authored by B, Party B appears to be exploiting Party A's identity for commercial benefit. ${ }^{236}$ In instances where an author's name is used without

F.R.D. 225, 227-28 (E.D. Pa. 1991):

Stating that nowhere on the outer covering of the album package do the names of Morvan and Pilatus appear, [defendant] avers that plaintiffs have assumed incorrectly that 7,000,000 persons purchased albums because Morvan and Pilatus were perceived as the actual singers. Defendants submit that individual testimony of each class member would be necessary to determine on what basis he or she made the purchase because the gravamen of the complaint is fraud. Essential to the claim of fraud is proof of reliance which may vary greatly among purchasers.

See also id. at 229 ("What causes a person to respond positively to a performance is a complex matter, especially in these modern times where popular musical performances involve visual as well as auditory stimulation.”).

233 See Mark A. Lemley, Rights of Attribution and Integrity in Online Communications, 1995 J. ONLINE. L. art. 2.

234 The theoretical foundation of the right of publicity is unclear. It originally stemmed from prohibitions against tortious invasions of privacy. Currently, it seems to sound in the proprietary concerns of copyright, but obviously can be employed in "sponsorship" circumstances highly similar to those which give rise to unfair competition claims. See J. Thomas McCarthy \& Paul M. Anderson, Protection of the Athlete's Identity: The Right of Publicity, Endorsements and Domain Names, 11 MARQ. SPORTS L. Rev. 195, 198 (2000) ("The right of publicity is not a kind of trademark. It is not just a species of copyright. And it is not merely another kind of privacy right. It is none of these things, although it bears some family resemblance to all three.”). For a well-known critique of the right, see Michael Madow, Private Ownership of Public Image: Popular Culture and Publicity Rights, 81 CAL. L. REV. 125, 178-237 (1993). For a response, see Kwall, supra note 25, at 3.

235 But this is not always a certainty by any means. For instance, in the Follett case, the New York Civil Rights law was found inapplicable to the situation, because Ken Follett gave permission to use his name and did not have a copyright in the underlying work. See Follett v. New Am. Library, Inc., 497 F. Supp. 304, 310 (S.D.N.Y. 1980). Another interesting possibility would be a claim of defamation, if the misattributed work was sufficiently damaging to an author's reputation.

${ }^{236}$ See, e.g., Winterland Concessions Co. v. MacIntosh, 1992 U.S. Dist. LEXIS 9917, at *25 (E.D. Pa. July 14, 1992) (finding that the sale of t-shirts bearing performer names such as “John Cougar Mellencamp” violated both Section 43(a) and rights of publicity). See also David W. Melville \& Harvey S. Perlman, Protection for Works of Authorship Through the Law of Unfair Competition: Right of Publicity and Common Law Copyright Reconsidered, 42 ST. LouIs U. L.J. 363, 392-93 (1998) (noting the historical expansion of publicity rights to cover distinguishing features like a singer's voice); Pinover, supra note 40, at 54-63 (explaining the similarities and differences between state publicity rights and attribution 
permission to sell a work of creative authorship that he did not create, authors can assert rights of publicity, and such claims have been successful. ${ }^{237}$ Yet rights of publicity as a mechanism for attribution protection have problems similar to those addressed above with regard to copyright. Because rights of publicity are often conceived of as something in the nature of property interests, they can effectively allow name "owners" the freedom to manipulate usages of authorial attribution. ${ }^{238}$ In other words, because concerns about consumer deception are not at all integral to the theory of rights of publicity, ${ }^{239}$ it would raise no red flags under the right of publicity for A to license B to sell a book attributed to A but written by B. If one believes authorial attribution protections are simply a matter of parceling out certain absolute grants to authors, rights of publicity seem to protect authorial rights fairly effectively (at least in the case of direct "passing off"). Yet the protection of societal interests in accurate attribution is entirely ignored.

In Part III, I will briefly delve into the dilemmas raised by private market orderings of proprietary rights in attribution and credit. My concern is that such systems, post-Dastar, may come to dominate and displace trademarkbased theories. Indeed, this is not so much a speculative concern as it is the current state of affairs. If we seek to protect social interests in accurate authorial attribution, no amount of copyright, rights of publicity, or proprietary "moral rights" will fully correct the problems raised by Dastar. Indeed, handing out more property rights to more authorial owners may ultimately make things worse for society. Until and unless we look to trademark's antideception theories to fix the result of Dastar, awarding new attribution "rights" will simply introduce a new stripe of property-like protection to an already crowded (arguably overcrowded, overcomplicated, and under-theorized) field of law.

claims under the Lanham Act).

237 See, e.g., Winterland Concessions, 1992 U.S. Dist. LEXIS 9917, at *25.

238 Pinover, supra note 40 ("Publicity rights do not have the same economic utility as trademarks. If consumers are not misled, there is no confusion in the product content conveyed to the consumer, and therefore, the consumer is not better able to predict anything about the product. Without consumer predictability, consistent quality in the product is not encouraged. ... Courts are justifiably cautious when dealing with a celebrity monopoly in an image.”); id. at 63 (arguing that consumer utility is enhanced by trademark protections for attribution, but is not enhanced by monopolistic proprietary schemes such as rights to publicity and moral rights).

239 See Estate of V.C. Andrews v. United States, 850 F. Supp. 1279, 1292-96 (E.D. Va. 1994) (using the principle of publicity rights to determine the value of an estate, but not taking into account the use of the deceased Andrews's name by another author as part of the publicity rights analysis); McCarthy \& Anderson, supra note 234, at 201 \& n.39 (noting that "deception or false endorsement is not required to prove a case of infringement of the right of publicity”). 


\section{AUTHORSHIP, CONSUMERS, AND COLLABORATION}

How can we know the dancer from the dance? ${ }^{240}$

In this Part, I will be looking at specific practices of authorial misattribution and fluid crediting. There are three points that I wish to make. First, attribution-shifting practices often occur in the marketing of information products for simple economic reasons. Second, there is a real potential for consumer deception in such practices, because authorial attribution, unlike a trademark, often points directly to a particular and relevant factual proposition about the circumstances of production and the qualities of a product. Third, some degree of this type of credit shifting is inevitable simply because there are significant limits in how far trademark can and should protect attributions of authorship. In the case of large-scale collaborative productions and in the case of authorship confusion that is intrinsic to a work, misattributions of individual authorship are probably not worth the social effort of policing. However the "authorship" in such cases lacks much of the unique value that has been discussed previously in this article. The associations of the names of directors and actors with large-scale collaborative film projects is not so much an issue of authorial attribution as it is a standard trademark issue of sponsorship and branding.

In order to explore these points, I will look at a few specific instances of credit-shifting practices in the promotion and sale of copyright-protected works. I will start out with some examples of ghostwriting. Ghostwriting seems a paradigmatic example of the differences between authorship concerns and standard trademark law. Neither the application of property-based attribution "rights" nor the application of standard trademark principles seem to be a very good fit for the protection of social interests in ascertaining authorship.

\section{A. Ghostwriting}

Ghostwriting is perhaps as old as authorship itself. Of course, this doesn't mean it is a good thing. Mahesh Grossman's recent book, Write a Book Without Lifting a Finger, states that its target audience is anyone who "fantasizes about seeing their name on a real published book."241 (Without lifting a finger, of course.) In its most aggressive form, where the attributed author writes nothing and the ghostwriter is completely unacknowledged, ghostwriting is pure plagiarism. ${ }^{242}$ In return for literary labor, the ghostwriter

${ }^{240}$ William Butler Yeats, Among School Children, reprinted in The Collected Poems of W.B. Yeats 215 (Richard J. Finneran II ed., 2d ed. MacMillan 1996).

241 Mahesh Grossman, Write a Book Without Lifting A Finger (2003). Presumably, Mahesh Grossman wrote the book, but who knows?

${ }^{242}$ As stated above, plagiarism is essentially the misattribution of authorship. See supra 
accepts financial compensation as a quid pro quo for a lack of credit. ${ }^{243}$ For instance, in the case of Hillary Clinton's book It Takes A Village, a ghostwriter was allegedly paid $\$ 120,000$ to provide literary services and, apparently in return, the existence of the ghostwriter was not disclosed on the book's cover or in the acknowledgements. ${ }^{24}$ Acknowledgement may be granted to a ghostwriter, but since the whole premise of ghostwriting seems to be about the misattribution of authorship, the more credit the ghostwriter gets, the less the activity appears like ghostwriting and the more it appears like collaboration. Ghostwriting is popular because it makes abundant market sense for both parties in the transaction. The fame of a politician, an athlete, a five-star general, or some other celebrity, can create a public demand for works of authorship created by that person. However, creative authorship generally requires substantial time, effort, and some degree of writing skill. Celebrities may not possess the time or skill, or be willing to invest the effort to produce quality authorial works. ${ }^{245}$ On the other hand, many skilled authors possess time and talent, but lack the popular appeal or fame that might allow them to sell their works to the public. So obviously, both the employer and the ghost have something worthwhile to gain from misleading the public as to the authorship of a literary work.

If one were to take an "authorial rights" approach to attribution and ghostwriting, it should be clear that the practice would be unproblematic. If a ghostwriter ("B") is paid to attribute her novel to the exclusive authorship of a well-known celebrity ("A"), this act is consensual among A and B. If the public is deceived by this misattribution of authorship, this is not problematic from the standpoint of either A or B. ${ }^{246}$ Even under analogies to trademark law, this type of "name licensing" seems unexceptional. A is simply licensing $\mathrm{B}$ to produce certain goods bearing the $\mathrm{A}^{\mathrm{TM}}$ mark. ${ }^{247}$ In order to say that any

note 66 .

243 The Follett case, discussed supra Part II.A.3, gives a standard example of this kind of negotiation for authorial credit. Follett v. New Am. Library, 497 F. Supp. 304, 313 (S.D.N.Y. 1974)

244 Charles Paul Freund, Living Hillary: The Art of Ghost-Reading, REAsON OnLINE, June 17, 2003, http://reason.com/links/links061703.shtml (criticizing Clinton for her alleged use of a ghostwriter for the books Living History and It Takes a Village).

245 Tomas Kellner, Under Cover, ForBes.COM, July 7, 2003, http://www.forbes.com/forbes/2003/0707/096.html ("Publishers covet celebrities, or even quasi-celebrities ... who offer juicy stories and built-in brand recognition. Fame brings big bucks: Bill Clinton will earn a reported $\$ 10$ million for his book, Whoopi Goldberg \$6 million and Ozzy Osbourne’s clan \$3 million. The hitch: 'Very often these people don’t have a clue how to read a book, much less to write one,' says Richard Pine, a New York book agent.”).

246 See supra note 97 and accompanying text (describing how commercial trademarks do not represent a single entity but a web of contractual relationships among producers of goods or services).

247 See id. 
harm is occurring here, we must assert that there is something about an inaccurate designation of authorship that can be misleading and potentially damaging to the public. ${ }^{248}$ In the case of a claim of individual authorship, it is not difficult to see that this is the case. Where the author is claimed to be a person, and not an amorphous symbol, attribution posits some meaningful connection between signifier and signified. If a consistent style of authorship can be ascertained from a careful scientific analysis of a given work, ${ }^{249}$ then to say that a person is an author is to point to a proposition that can be factually true or false. This proposition is arguably much more significant than any thing pointed to by a trademark. Thus, misattributions of authorship may create harms to consumers that are more serious than the harms created by the misleading use of trademarks.

Yet ghostwriting demonstrates that such deceptions are sometimes "licensed" by both the true and falsely credited authors. Even celebrated writers have ghostwriters. It may seem odd to think that those who gain their fame through the labors of literary art would be inclined to let others write under their names, but it happens. Tom Clancy, for example, is a worldfamous author of spy thrillers such as The Hunt for Red October, Patriot Games, and The Cardinal of the Kremlin. ${ }^{250}$ His success with these books has been leveraged into a multi-media empire of films, computer games, and television programs. ${ }^{251}$ Tom Clancy's Op-Center: Line of Control is one book in an Op-Center series currently being sold in stores. The name "Tom Clancy" appears five times on the front and back cover of the paperback (including in 80 -point type on the top of the cover). ${ }^{252}$

The Op-Center books, however, were all written by Jeff Rovin. ${ }^{253}$ Line of Control's cover does, in a very small typeface on the bottom of the front cover, declare it was "written by Jeff Rovin" - although only after it states (in addition to all the other Clancy marks) that the book was "Created by Tom Clancy and Steve Pieczenik." This is likely somewhat confusing to the average consumer. Line of Control was shelved at my local library, by author, in the "C" section. ${ }^{254}$ (Perhaps this misshelving might be explained by the fact

\footnotetext{
248 See 3 MCCARTHY § 24.03[2], supra note 100, at 24-13 (characterizing the purpose of trademark law as the prevention of consumer confusion leading to inefficient purchasing).

${ }^{249}$ See supra note 8 (describing high-tech tools for determining the identities of authors and artists).

${ }^{250}$ Wikipedia: Tom Clancy, http://en.wikipedia.org/wiki/Tom_Clancy (last visited Aug. 12, 2005)

251 Id. (reporting on Clancy’s many novels, ghostwritten novels, films, and videogames).

252 JefF Rovin, Tom Clancy's Op-Center: Line of Control (2001) (displaying Clancy's name prominently on its cover).

${ }^{253} I d$.

${ }^{254}$ I actually spoke briefly with my township librarian about this. She concluded that the book was technically misshelved. In subsequent visits, I've noticed that the book remains technically misshelved.
} 
that the first six books in the Op-Center series reportedly did not indicate on the cover that Rovin was also the author of those books. ${ }^{255}$ )

Tom Clancy did not collaborate in writing the Op-Center books, at least as most consumers would understand that word. He apparently brainstormed a bit, in a telephone conversation, the basic concept of a television series upon which the books are based. ${ }^{256}$ He then contracted to allow Rovin to write the Op-Center books under his name. ${ }^{257}$ Many purchasers, however, were understandably unaware of the underlying circumstances of the "creation" of the book by Clancy. Instead, many purchasers seemed to read the Op-Center series with the mistaken impression that Tom Clancy actually wrote the books. On Amazon.com, some volunteer reviewers of Tom Clancy's Op-Center: Line of Control have praised the book as, e.g., "an excellent thriller by Tom Clancy" while others have panned the book by stating, e.g., that "Tom Clancy is clearly overreaching in this incoherent and rambling book set in Kashmir."258 Other reviewers express disappointment with the quality of the writing coupled with a statement that the purchaser mistakenly believed that Tom Clancy had something to do with the book's authorship - but the reviewer has since grasped the truth. ${ }^{259}$ According to recent news reports, Clancy is complaining that the Rovin-authored Clancy books are destroying his authorial reputation yet he finds himself unable to escape from his contract with Rovin. ${ }^{260}$ Of

255 See Roger Friedman, Tom Clancy's Jack Ryan Replaced by Gen-X Version, Fox NEws, Aug. 1, 2003, http://www.foxnews.com/story/0,2933,93515,00.html (stating that Rovin's name did not appear on the first six installments of the Op-Center series).

256 See Arthur Santana, Judge Set to Rule on Clancy Venture, Wash. Post, Sept. 12, 2004, at T3 (reporting that Clancy became interested in the "Op-Center" project as a planned miniseries).

257 See Friedman, supra note 255.

258 See Amazon.com Reviews of Tom Clancy's Op-Center: Line of Control, http://www.amazon.com (search "Line of Control," then follow "Line of Control” link in results list) (last viewed Aug. 12, 2005).

259 The pseudonymous reviewer “Big Dog,” from Christchurch, New Zealand, wrote: I based my purchase on two things. One, I thought Tom Clancy had something to do with it. And two, the blurb on the back seemed interesting. Well, I was mislead on both counts. I cannot for the life of me spot any influence from Tom Clancy - there is truly something wrong in the literary world when the cover of the book has the author in the smallest letters at the bottom.

Id. Something also might be read into the fact that used copies of Tom Clancy's Op-Center: Line of Control were on sale in 2004 on Amazon.com at the price of one penny (plus shipping). Id.

${ }^{260}$ See Nancy Kercheval, Tom Clancy Seeks New Fans amid Turmoil with Ex, THE DAILY RECORD, Aug. 30, 2004, available at http://www.mddailyrecord.net/pub/5_51_monday/businessnews/159181-1.html:

Clancy ... has branded several series, including the "Op-Center" series of 14 books and the video game 'Splinter Cell.' [T] million to just under 600,000, despite commanding advances of $\$ 2.25$ million for the next two installments ... . Clancy's former wife ... whom he divorced in 1999 after 
course, this has led to litigation. ${ }^{261}$

Another world-famous author, Virginia Cleo Andrews, is also having books produced under her name. V.C. Andrews gained her fame by writing pulp horror novels involving troubled young girls surviving perverse torments inflicted by demented adults. ${ }^{262}$ The appeal of this niche may be elusive to the adult reader - and publishers didn't see it at first either. Flowers in the Attic, Andrews's first novel, was rejected seven times before it found a publisher in 1977. ${ }^{263}$ After publication, however, the book became a phenomenon, finding popularity with (of course) young girls. ${ }^{264}$ A few years after Flowers in the Attic was published, V.C. Andrews was an international literary star, securing million-dollar advances for her novels. ${ }^{265}$ However, she increasingly felt trapped in her "troubled children" niche. She made two efforts in the 1980s to break away from stories of suffering children and demented adults - but her publisher rejected both. ${ }^{266}$ Little did she know how long she would be trapped in the profitable formula. In 2003, one could find copies of the new V.C. Andrews novel Midnight Flight for sale in bookstores everywhere - another story of "troubled girls" subject to mistreatment by demented adults. ${ }^{267}$ The cover of Midnight Flight states that the book is "[t]he thrilling sequel to Broken Wings - from New York times bestselling author, V.C. Andrews.” The name "V.C. Andrews" is emblazoned on the book in 160-point drop-shadow and relief letters. $^{268}$

Yet V.C. Andrews did not write Midnight Flight or many other books attributed to her. She died in 1986. ${ }^{269}$ After her death (and apparently without ever having ascertained her preferences in the matter) her publisher was suddenly struck with the idea of continuing to produce books attributed to the

30 years, challenged his decision to withdraw his name from 'Tom Clancy's OpCenter' series, saying the books would be worthless .... Circuit Judge Warren J. Krug... ruled that Clancy's right to his own name is ambiguous, and therefore, allowed the lawsuit to proceed.

(on file with author).

${ }^{261} I d$. (noting the judge's decision to allow the suit to go forward).

262 Estate of V.C. Andrews v. United States, 850 F. Supp. 1279, 1281 (E.D. Va. 1994)

(describing the characteristics of the genre and Andrews's success with it).

${ }^{263} \mathrm{Id}$.

${ }^{264} \mathrm{Id}$. (stating that the genre "was particularly appealing to teenagers and young women").

265 Id.

266 Id. at 1282.

267 V.C. AndREws, Midnight Flight (Pocket Star 2003).

${ }^{268} I d$.

269 See Estate of V.C. Andrews, 850 F. Supp. at 1281 (giving Andrews's date of death as December 19, 1986); David Streitfeld, A Novelist's Tales from the Crypt: V.C. Andrews Died in 1986 but Her Horror Books Keep Coming, WAsH. Post, May 7, 1993, at A1 (concluding that Andrews has been "more prolific dead than alive"). 
authorship of V.C. Andrews. ${ }^{270}$ Her agent independently arrived at the same idea. The estate also agreed that the death of the author shouldn't be an impediment to the life of profits. ${ }^{271}$ Andrew Neiderman, an English teacher in New York, was recruited to be the undisclosed ghostwriter. ${ }^{272}$ Neiderman received $\$ 250,000$ of the original $\$ 1.5$ million advance, while the rest went to the estate. ${ }^{273}$ While this was obviously not a significant portion of the literary proceeds, \$250,000 was several times greater than any previous advance Neiderman had received for his own works of horror fiction published under his own name. ${ }^{274}$ Luckily for everyone (except, perhaps, V.C. Andrews), the Neiderman books continued to sell. ${ }^{275}$ Subsequently, an IRS auditor learned of the immense profits that the Andrews estate was reaping from the continued exploitation of the V.C. Andrews name, and assessed the estate $\$ 649,201.77$ in unpaid estate tax and interest on the $\$ 1,244,910.80$ post-mortem value of the use of Andrews's name in conjunction with the misattributed novels. ${ }^{276}$ This led to a courtroom battle and a judicial order slightly reducing the IRS assessment, in part due to the financial risks inherent in attempting to deceive the public into believing that a dead author was still writing books. ${ }^{277}$ Today,

270 Jack Romanos, head of Simon \& Schuster's mass market division, conceived the idea. He explains that after Andrews's death, “[w]e were sitting around and it occurred to me that it was possible if we could find a writer . . . who could mimic Virginia’s style, that we might be able to continue to publish." Streitfeld, supra note 269, at A1. Andrews's literary agent had the same idea: "she never was a celebrity in this country, which made it easier for people to forget she was dead. It would be very difficult to do this with Danielle Steele." Id.

271 See id. (noting that the estate has "profited handsomely" from the posthumous books).

${ }^{272} I d$.

273 Id.

${ }^{274}$ Id. (stating that Neiderman "had written some horror novels himself, although much less successfully than Andrews”).

275 But this doesn't mean that the customers are happy. Many volunteer reviewers on Amazon.com - even those who give Midnight Flight positive ratings - implore either the ghost-writer or the family to stop using the V.C. Andrew's name. For instance, "Stephanie" from Washington, D.C. liked the book, but writes:

why can't he stop putting VCA as the author? It would make more sense now as I have more [ghostwritten] books on my shelf than [Andrews's books] because she wrote so few on her own. Use your own name[, ghostwriter]. It will be okay, and maybe better cause we can stop holding you up to VCA (The Queen).

The interestingly named "Gertrude Snuffenheimer" from Atlanta, on the other hand, writes: "[t]his is shameful. Poor V.C., rolling around in her grave as I write this. Why does the [ghostwriter] insist on driving her good name through the mud? I never even finished Broken Wings, and this one just tops off the true V.C. genius abuse." See Amazon.com Reviews of Midnight Flight, http://www.amazon.com (search "Midnight Flight," follow "Midnight Flight” link, then follow "See all customer reviews” link) (last visited Aug. 12, 2005).

276 Estate of V.C. Andrews v. United States, 850 F. Supp. 1279, 1281 (E.D. Va. 1994).

277 Id. at 1295 (reducing the tax assessment of the value of Andrews's name by thirty- 
even after a Washington Post newspaper article, the misattribution of V.C. Andrews novels continues. ${ }^{278}$

Given the public's awareness of the ghostwriting in the cases of Clancy and Andrews, and the apparent nonchalance and lack of embarrassment of the parties engaged in the practice, one may well wonder how deep the rabbit-hole of ghostwriting goes in the publishing industry. Because the uses of Tom Clancy's and V.C. Andrews's names in the sale of books comport fairly well with theories of rights of publicity and even standard approaches to trademarks, there seems little reason to suspect that there are substantial checks being placed on ghostwriting practices.

But if we take a social perspective on the value of authorial attributions, none of this should sit well. Authorial "licensing" is made valuable by a form of consumer deception that is inimical to the traditional consumer protection rationale of trademark. ${ }^{279}$ Misattribution of authorial identity is valuable to those who engage in it precisely because it deceives the public. ${ }^{280}$ Even from the perspective of an incentives theory, it isn't at all clear that ghostwriting provides any public benefits. Has the sale of books by Clancy ${ }^{\mathrm{TM}}$ (Rovin) or V.C. Andrews ${ }^{\mathrm{TM}}$ (Neiderman) been beneficial to the public? It seems clear that traditional trademark law does not map neatly onto authorship in some instances. In order to protect the public interest, one would need to be much more restrictive in granting personal name "owners" the freedom to "license" their authorial attributions. This aligns with Professor McCarthy's observation that the law must "insur[e] that the assignee's use of the mark will not be deceptive, and will not break the continuity of the thing symbolized by the

three percent to account for the risk involved).

278 At some point, a tiny disclaimer was added to the copyright page of the book stating that Andrews is dead. V.C. Andrews, Midnight Flight (2003). However, as in the Clancy example, this gesture at informational veracity is small, ambiguous, and hard to reconcile with the bold authorial attribution on the covers of the books, which everyone seems to admit is what drives the sale of the books. The Simon \& Schuster web page for V.C. Andrews seems to fully recognize that readers are interested in the identity of the author. It contains many photos of Andrews, a brief biography of her early life, and a list of her current paperbacks for sale. However, it has no pictures of Andrew Neiderman; it fails to distinguish between the Neiderman and Andrews books; and it does not mention that V.C. Andrews died some years ago. See Simon Says: V.C. Andrews, http://www.simonsays.com/content/content.cfm?sid=33\&pid=330975 (last viewed Aug. 12, 2005) (follow “Image Gallery” link).

279 For some thoughts along these lines, see Green, supra note 25, at 190 ("[T]he author's consent should not be a defense to plagiarism.”); Pinover, supra note 40, at 41 (observing that ghostwriting, which is essentially authorized reversed passing off, "does not cure the deception of the consuming public").

280 See Estate of V.C. Andrews, 850 F. Supp. at 1284-85 (explaining that measures were taken to "maintain the illusion" that the ghostwritten books were Andrews' work, because “Andrews' name was central to the promotional effort”). 
assigned mark."281 If authorial attribution interests are to be protected under trademark-type theories, they must be protected in a way that is unlike traditional trademark protections. Attribution must be bounded to some factual and socially valuable truth about the identity of the true author. In other words, in the case of authorial attribution, trademark law should ensure the reliability of consumer beliefs about the connection between claims of authorship and the true process of the work's creation. Consumer beliefs can vary according to the type of work at issue, as will be discussed in the next section.

\section{B. Collaborative Authorship and Social Value}

In ghostwriting, where the attributed author writes nothing and the existence of the ghostwriter is undisclosed, we clearly are faced with certain problems as set forth above. However, in some instances of ghostwriting, an attributed author will make some contribution to a literary production. Also, a ghostwriter occasionally obtains some acknowledgement for contributions. Collaborations between celebrities and skilled authors are sometimes truthfully marketed as such. Thus, the situation of ghostwriting simply marks one extreme position within a much broader spectrum of comparative attribution issues in cases where collaborators produce creative works. In instances of collaboration, the same dynamics that fuel ghostwriting will often lead to marketing strategies that promote to the public the reputation of the prominent author - even where the parties contribute equally. An example might be taken from the recent literary output of the Supreme Court. In the year before the decision in Dastar, Justice Sandra Day O'Connor published a book about her early childhood: Lazy B: Growing Up on a Cattle Ranch in the American Southwest. ${ }^{282}$ She collaborated on the book with H. Alan Day, her brother. Day is a lifelong cattle rancher (and writer) who ran the Lazy B ranch for thirty years. ${ }^{283}$ According to USA Today, Day provided O'Connor with the "material” for the book, which O'Connor then revised and reorganized. ${ }^{284}$

Just as Doubleday knew that Eisenhower's authorship could sell copies of

2813 MCCARThY $\S 18: 2$, supra note 100 , at 18-8 to 18-9; Fair Undercar Care, Inc. v. Wakefield, 1992 U.S. Dist. LEXIS 10120, at *16 (N.D. Ill. July 2, 1992) (citing MCCARTHY).

282 SANDRA Day O’CONNOR \& Alan DAy, LAZY B: GROWING Up ON a CATTLE RANCH IN THE AMERICAN SOUTHWEST (hardcover ed., Random House 2002).

283 Deirdre Donahue, Even Cowgirls Get to the High Court, USA TODAY, Jan. 21, 2002, at $1 \mathrm{D}$ (reporting that Day "remained on the ranch, managing it for 30 years after graduating from the University of Arizona”).

284 According to USA Today, "[b]oth siblings agree that Day possesses more 'institutional memories.' He would write material for the book, then his sister would revise and reorganize his original drafts. They also would meet, correspond and compare their memories. O’Connor eliminated Day's chapter, 'My Sister Sandra.'” Donahue, supra note 283. 
Crusade in Europe, publisher Random House surely knew that Justice O’Connor's authorship could sell copies of Lazy B. Indeed, just as Crusade in Europe was marketed as being Eisenhower writing about his memories of World War II, Lazy B was marketed as Justice O'Connor writing about her memories of childhood. O'Connor's authorial designation appears on the cover at roughly twice the size of her brother's (four times as large on the paperback), O'Connor's picture appears on the cover, ${ }^{285}$ O'Connor reads aloud the audiobook version, and - perhaps most importantly - the book is written using the first person voice of Justice O'Connor. ${ }^{286}$ Even chapters that deal primarily with Alan Day and his private thoughts are also written in the voice of O'Connor. ${ }^{287}$ Given the collaborative nature of the book's production and its topic, there was obviously some inherent potential for consumer confusion as to the authorship of Lazy B. Some readers undoubtedly bought the book to gain a glimpse into the thinking of one of the most influential Supreme Court Justices of the last century. Instead, they found a great many details about cattle ranching. This is not to say that there was anything misleading about the book. But it does point out how the marketing of collaborative authorship is influenced by the gravitational pull of one author's celebrity. The mechanics of production may be influenced by other factors. Even where collaboration is fully disclosed, when consumers misestimate the type and degree of collaboration that can be expected, they may be disappointed. ${ }^{288}$

Yet many, perhaps most, entertainment products for sale today are produced by similar processes of collaborative authorship. ${ }^{289}$ In the case of film, for

285 O’CONNOR \& DAY, supra note 282; SANDRA DAY O’CONNOR \& AlAN DAY, LAZY B: Growing Up on a CATtle Ranch in the American Southwest (paperback ed., Random House 2003).

286 See O’CONNOR \& DAY, supra note 282, at 6 (narrating in the first person).

${ }^{287}$ Id. at 213-225. For example, Chapter 20 is primarily about Day and his horse, Saber, and seems a strange fit with the first person voice of Justice O'Connor. The use of O'Connor's point of view requires Day's thoughts to be rendered in the third person. See, e.g., id. at 224:

Alan picked up a big half-Brahma cow that looked pretty athletic and decided to turn Saber loose on her. Alan had always held him back a little and had never really let him loose on a cow to run her and turn her back because he was so powerful and so fast. Alan always wanted to throttle him back a little. This time, just for fun, Alan turned the old cow up the fence.... He let the reins go slack and thought, "Well, let's see what happens here."

The excised "My Sister Sandra" chapter obviously would have been even more difficult to reconcile with O’Connor's first person voice. See supra note 284.

288 There has been an interesting recent trend, in a similar family vein, of collaborations among parental authors and their children. In some cases, the children continue to write in the same literary genre of the parent. The family name "brand" of the parent is recognized by the public, the intellectual property licenses are probably not so hard to negotiate, and some degree of familiarity with the material might be reasonably presumed on the part of the child. Of course, one wonders if authorial expertise and talent are hereditary.

289 See Hunter \& Lastowka, supra note 26, at 979 (observing that many creative works 
instance, there are often hundreds of authors. The film Saving Private Ryan was marketed as a "Steven Spielberg film," yet it involved the creative contributions of over 700 individuals. ${ }^{290}$ The list of authors whose contributions created stylistic "fingerprints" on Saving Private Ryan is obviously extremely long. It is so long that it would clearly be beyond the interest, as well as beyond the ability, of the average consumer to remember the names of these individuals and to understand what each individual contributed to the film. It is unlikely that director Steven Spielberg knows who deserves personal credit for each aspect of the film. The Dastar Court was correct to recognize that consumers may not be interested in all information regarding authorship of collaborative creations. ${ }^{291}$

So how does this modify the conclusions in the previous section? Obviously, in cases involving more than two or three authors who contribute to a single work, consumer interests in ascertaining the details of a work's authorship can become much more diffused. ${ }^{292}$ In the case of written works, if the public purchases a book it believes to be authored by Tom Clancy or V.C. Andrews, we can say that the public has been deceived if Tom Clancy or V.C. Andrews did not, in fact, make a substantial authorial contribution to the authorship of the purchased book. If the public purchases a "Steven Spielberg" movie, however, the public will not be deceived if it finds out that Spielberg did not personally write the script, create the costumes, compose the music, and act all the parts. ${ }^{293}$ The public is aware that Spielberg instead supervised, partially controlled and had some auteur influence over various aspects of the movie.

Steven Spielberg's directorial role in Saving Private Ryan is clearly relevant to consumers. The fact that Spielberg could manage to get his name put on the film seems to validate the point that his authorial attribution provides some

are now produced by committee).

290 See Saving Private Ryan: Full Cast and Crew, The Internet Movie Database, http://www.imdb.com/title/tt0120815/fullcredits (last visited Sept. 17, 2005).

291 An unidentified Justice stated during oral argument in the Dastar case that film credits are generally something that "no one ever reads." Transcript of Oral Argument at 51, Dastar Corp. v. Twentieth Century Fox Film Corp., 539 U.S. 23 (2003) (No. 02-428) (“I mean, the screen credits, you know, you're going to the refrigerator or reading cert petitions or something."); cf. Dastar, 539 U.S. at 35-36 ("We do not think the Lanham Act requires this search for the source of the Nile and all its tributaries.”).

292 This isn't to say that crediting in instances of large-scale collaboration is not of interest to some segment of the public. Within creative industries, credits can be extremely important. Indeed, it was the presumed importance of film credits to actors and the film industry that led the Ninth Circuit to adopt the "bodily appropriation" doctrine. See Cleary v. News Corp., 30 F.3d 1255, 1261 (9th Cir. 1994).

293 Nor does copyright law grant much weight to screen credits. See Dougherty, supra note 217, at 313 ("A person is not an author under U.S. law simply because he is called the director or is credited as the director on screen. The fundamental question under U.S. law is: Who originated a particular expression?”). 
value. Again, Post-it ${ }^{\mathrm{TM}}$ Notes could be, but aren't, distributed with similar attributions. ${ }^{294}$ Primary marketing attribution is often used as an additional form of incentive and compensation. Key parties in the film process will often wrangle and even litigate over their right to be promoted as the creative force behind a project. ${ }^{295}$ The end result of this process (which is additionally regulated in minute detail by the various guilds and collective bargaining agreements) is a particular presentation and marketing of a film's "authorship" to the public. This marketing usually promotes a very small subset of actual authors - perhaps a director, a lead actor, and/or another significant contributor, such as the author of a book that is being adapted. ${ }^{296}$ In the case of Saving Private Ryan, Steven Spielberg, Tom Hanks, and Matt Damon were the primary brands under which the film was marketed. 297

For the public, this kind of personal "branding" of collaborative efforts, while it may not explain much about the details of the complicated process of authorship, can still provide important information in much the same way that a traditional trademark provides some useful information. As stated above, the word "Nike" on a sneaker generally means very little to a consumer in terms of actual information. Likewise, the fact that a certain person has been associated with a certain project may say very little about any personal involvement with the work's creation. But if that person has previously appeared in association with high quality creative works, this can be taken by the public as some indication that the new film's quality and characteristics will be the same as those previously associated with that actor or director. ${ }^{298}$ Society certainly

${ }^{294}$ Similarly, the end credits of a motion picture, even the most obscure ones, are not simply superfluous nonsense. They are surely relevant as a personal motivator to those engaged in film production, and may also be useful within the movie industry. Those professionals who understand the making of films may have an interest in knowing the identities of individuals behind creative contributions, and credits can help individuals secure work on later projects. MELVIN SiMENSKY ET AL., ENTERTAINMENT LAW 1005-1120 (3d ed. 2003). This is not to suggest, however, that these long lists of film credits provide much of value to the average consumer.

295 See generally Gulick, supra note 113 (discussing attribution practices and negotiations in film crediting); see also SIMENSKY ET AL., supra note 294, at 1005-20 (discussing contractual disputes over credit obligations); Gulick, supra note 113 at 87 ("For directors such as Warren Beatty and Woody Allen, the granting of the [final cut] right is in the interests of the producers, who view it as a simple exchange for access to the proven economic success of the director's name and reputation.”).

296 One can get a sense of how marketing concerns, financial power, and artistic ego collide by looking at any group of movie posters and comparing the size and placement of the names of actors, producers, directors, and (in some cases) the novelists, playwrights, or other persons that provided the inspiration for the film.

297 And, in turn, the film's success further promoted the strength of these brands.

298 Gulick, supra note 113, at 100:

When a consumer thinks of the author of a film, he thinks of its artistic, not legal, author.... For consumers, the attribution of a film's source to its director functions 
recognizes the brand value of the participation of Julia Roberts or George Clooney with a film project. The public knows that these names and reputations are placed on the line by association with the project - if the project fails, the branded celebrity will suffer a loss of public reputation. Thus, practices of authorial attribution where certain personalities reap credit for the efforts of large collaborative teams operate in much the same way that trademark identifiers establish consumer associations with the collaborative production of business, corporate, and contractually licensed entities. ${ }^{299}$ In the case of large-scale collaboration, the basis for trademark protection becomes much more analogous to the traditional reputation and endorsement dynamics. 300

However, the difference between authorship and trademark in the case of collaborative enterprises also suggests that a deviation from normal trademark doctrine is warranted. Claims of reverse passing off are hard to justify where the choice of any particular personal association with a work of collective authorship is largely arbitrary. Because traditional trademarks designate collective enterprises, reverse passing off arguably promotes greater truth in communication in an economical fashion. In the case of large-scale projects, such as films, none of the myriad of authors clearly deserves to be one of the subset of persons who have their authorial identities explicitly advertised and promoted in association with the work. It would seem impossible to allow, for instance, each of several hundred contributors to a film to claim that a work was being "passed off" where they were not attributed with authorship in conjunction with the sale of the work. Additionally, as the Dastar court noted, the corporate publisher (the copyright "author") of a film and the manufacturer of the film's tangible medium are largely irrelevant to consumers - thus reverse passing off, as applied to those entities, will serve no socially useful purpose. ${ }^{301}$ In the case of collaborative authorship, it seems the justification for the doctrine of reverse passing off falls away. The Dastar case reaches the right results, but for the wrong reasons.

The difference between collaborative and individual authorship with regard to reverse passing off is significant. The attribution of authorship, or the

like a brand-name identifier. ... There is a certain value to consumers to the extent that they form these associations, for they save on search and information costs.

299 See Hughes, supra note 18 (discussing how common trademarks such as Sara Lee represent collaborations between several corporate entities).

300 Indeed, some popular "authors" are artificial constructs. For instance, bands like Alvin and the Chipmunks and the contemporary band Gorillaz feature animated cartoons as musicians, essentially attributing musical talent to fictional authors that are collaboratively produced. See Gorillaz, http://www.gorillaz.com/ (last visited Aug. 12, 2005) (official website). For a high-tech take on the animated celebrity, see the recent film Simone (New Line Cinema 2002).

301 Dastar Corp. v. Twentieth Century Fox Film Corp., 539 U.S. 23, 32 (2003) ("The purchaser of a novel is interested not merely, if at all, in the identity of the producer of the physical tome....”). 
failure to attribute authorship, in the case of a singular author (or a small set of authors) carries with it some degree of socially important empirical truth. Thus, ghostwriting should be actionable as a form of reverse passing off. By contrast, large-scale collaborative efforts disassociate the authorship mark from any factually meaningful information about the product.

\section{The Limits of Attribution Protection}

Finally, I would like to suggest that any application of trademark law to works of authorship must be limited to marks that meet three criteria: 1) they should be prominently placed (or deserve to be placed) on the exterior of the work; 2) they should be placed (or deserve to be placed) there with the hope of establishing goodwill and driving sales of the product; and 3) they should serve to designate creative authorship to readers who would care about this authorship. None of these requirements is particularly unusual under traditional notions of trademark law. Trademark law has traditionally focused on extrinsic marks placed on the exteriors of products, ${ }^{302}$ and has sought to protect consumers against confusion as to the source of products where such confusion will lead to ill-informed purchases. ${ }^{303}$

Yet in the current climate of trademark regulation, authorship protections could clearly extend beyond this point. Indeed, the Ninth Circuit case of Smith v. Montoro, ${ }^{304}$ relied upon by the lower courts in the Dastar case and overruled by Dastar, was essentially an attempt to regulate the crediting of component parts of a work under a theory of trademark. ${ }^{305}$ Smith, and courts that relied upon it, suggested that credit sequences of films were an appropriate concern of trademark law. ${ }^{306}$ If one approaches trademark regulation from the standpoint of anti-plagiarism norms, moral rights arguments, or analogies to rights of publicity, one might argue that the result in Smith v. Montoro is justified. The criteria above, however, would not extend so far. I would suggest that if we regulate authorship designations pursuant to trademark law, we should do it in a way that comports with a very conservative approach to the goals of trademark regulation.

I make this qualification somewhat reluctantly. There are arguments to be made for broader protections. Consumer deception can certainly occur with regard to the authorship of component pieces of creative work. Our social norms against plagiarism do not just condemn the misattribution of entire works of authorship where those misattributions are made on the exterior surfaces of works sold in commerce. Instead, anti-plagiarism norms extend to

302 Rogers, supra note 73 (characterizing the origins of trademark law in the regulation of guild emblems on goods).

303 Dastar, 539 U.S. at 34 (describing the purpose of trademark law).

304648 F.2d 602 (9th Cir. 1981).

${ }^{305} \mathrm{Id}$. at 605 (finding that trademark law properly applied to the substitution of one actor's name for another in a film's credits and advertising).

306 See id. 
condemn much more fine-grained instances of misattribution, where authors borrow phrases or ideas without attribution. Plagiarism concerns itself with appropriate credit for the multiple bits and pieces of a work. ${ }^{307}$ However, none of the recent plagiarism scandals mentioned in the introduction would run afoul of my proposed standard. Why not extend the standard further? To extend regulation of attribution as finely as plagiarism would reach would likely prove overly burdensome for authors, readers, and the court system. The burden of writing, reading, and regulating extensive footnotes and credit lists for every creative text sold to the public is not an obligation one would want to impose on the entertainment business or the purchasing public. Creativity itself is often merely a practice of finding bits and pieces of the works of others and assembling them into a new unified whole. ${ }^{308}$ Because all words and symbols must refer to prior words and symbols simply in order to be intelligible, all new works must borrow from prior works to some degree. 309 To insert law into this process by regulating authorial attribution for the bits and pieces of authorship contained inside texts would almost certainly lead to the disclosure of more information than any consumer would care to know.

\section{Extrinsic and Intrinsic Crediting: Vocal Dubbing}

To show the effect of a conservative approach in practice, we might take, for example, the practice of vocal dubbing. In vocal dubbing, one person's voice is directly blended with the image of another person's vocalizing. One can see that vocal dubbing might easily raise concerns very similar to those raised by ghostwriting. If Tom Clancy, for instance, is credited (and shown on music videos) as the vocalist on an album of great Broadway show tunes, some of his admiring public may be inclined to purchase the album. If Jeff Rovin were actually singing the songs, however, this would be a deceptive designation of authorship. ${ }^{310}$ Where the item for sale is a musical work, and the authorship of the vocal performance is clearly a primary concern of the purchaser, this type

307 See generally PERSPECTIVES ON Plagiarism AND INTELleCtUAL PROPERTY IN A POSTMODERn WORLD (Lise Buranen \& Alice M. Roy eds., 1999); Malcolm Gladwell, Something Borrowed, THE NEW YORKER, Nov. 22, 2004, at 40 (describing how a psychiatrist tracked "thematic similarities" between her book and a play she alleged was plagiarized from it).

308 There are many other words for this process, e.g., collage, collection, arrangement, found art, etc. For some thoughts on the importance of this process to art and its limits, see generally Gladwell, supra note 307 (discussing the work of playwright Bryony Lavery and her use of sources in the Broadway play Frozen).

309 See, e.g., Note, Originality, 115 HARV. L. REV. 1988, 1990 (2002) (asserting that "all writing is, in some sense, rewriting”).

310 Ventriloquism and puppetry are essentially ancient technologies of dubbing. These uses do not strike most adults as deceptive, however, because they must take place within the realm of suspended disbelief. (We all know puppets can't talk.) Animation today is another popular and unproblematic use of dubbing. 
of deception should be actionable under trademark law. My proposed line, however, would separate this hypothetical situation from more common instances of vocal dubbing. Vocal dubbing in a film, for instance, would likely not be actionable. As stated above, the consumer concerns over particular component pieces of authorship within a work are more diffuse.

Is there a public interest in preventing vocal dubbing in collaborative efforts? Consider the classic Hollywood film Singin' in the Rain. ${ }^{311}$ The film is set during the revolutionary point in film history when the industry was being transformed from the era of silent film to the era of contemporary "talkies." In the movie, Gene Kelly plays the part of Don Lockwood, a former vaudevillian and stuntman turned celebrity actor. ${ }^{312}$ When a major film project fails due to his co-star's poor vocal talents, Lockwood proposes that his love interest, the aspiring actress Kathy Selden (played by Debbie Reynolds) should provide the on-screen singing voice of the acoustically challenged Lina Lamont (played by Jean Hagen). Both Lockwood and Selden are aware that this practice will mislead the public as to Lamont's singing talents, and also won't do much to promote Selden's career. Yet Selden agrees to the arrangement in order to save Lockwood's career from ruin. What seems a perfect idea at first leads to predictable comedic complications: Lamont demands that Selden be required to dub her singing vocals permanently and threatens the head of the studio if he does not comply with her demands. ${ }^{313}$ At the film's premiere, Lockwood and the owner of the film studio create a ruse to reveal the dubbing. They demand that Selden must sing for Lamont, live, behind a curtain while Lamont lip-synchs. Selden grows indignant, but complies. In the film's climax, Lockwood and the studio head literally raise the curtain on the undisclosed Selden/Lamont collaboration. This public disclosure of Selden's vocal dubbing for Lamont both humiliates Lamont and catapults Selden into Hollywood stardom. ${ }^{314}$

The moral of the film seems clear - Lamont's claiming credit for the work of Selden was deceptive. The film suggests that the public will hold the Lamonts of the world in contempt and will support the Seldens, the true and

311 Singin’ In the Rain (Metro-Goldwyn Mayer 1952). Perhaps the film is such a classic in Hollywood because it is all about Hollywood. It provides parodies of real personalities in the movie industry - language coaches, egomaniacal studio heads, aspiring starlets who profess to be concerned about high art, and venomous divas threatening to bankrupt studios.

312 See Singin' in the Rain: Full Cast and Crew, The Internet Movie Database, http://www.imdb.com/title/tt0045152/fullcredits (last visited Aug. 12, 2005).

${ }^{313}$ Lamont explicitly evokes her legal and contractual rights:

I had my lawyer go over my contract. ... The studio's responsible for every word printed about me. If I don't like it, I can sue, I can sue. If you tell the papers about Kathy Selden, it would be detrimental and deleterious to my career. I could sue you for the whole studio.

Singin’ IN THE RAIN (Metro-Goldwyn Mayer 1952).

${ }^{314}$ Id. 
talented vocal authors. During the late 1980s, the pop music duo Milli Vanilli found themselves re-enacting this morality play. Charles Shaw, John Davis, and Brad Howe played the part of Selden. ${ }^{315}$ The trio had vocal talent, but they were getting older and had been deemed (by their manager) unmarketable to the MTV generation. So their manager hired aspiring dancer/models Rob Pilatus and Fabrice Morvan to be Lamonts, lip-synching the trio's songs. The arrangement worked fantastically - everyone thought Pilatus and Morvan were actually singing the songs. In 1990, Milli Vanilli won a coveted Grammy Award for Best New Artist (beating out the Indigo Girls and rapper ToneLoc). ${ }^{316}$ Pilatus and Morvan were overnight celebrities. They pressed their manager to let them sing on their next album. The band's manager, apparently overwhelmed by orchestrating the deception and dealing with competing demands (much like the studio owner in Singin' in the Rain), raised the curtain on the lip-synching. ${ }^{317}$ The public was appropriately shocked, the Grammy Award was revoked, and the band became a scapegoat for all that was inauthentic about popular music. ${ }^{318}$ And yes, a lawsuit was filed on behalf of a wronged public. ${ }^{319}$ Like Lamont before them, Pilatus and Morvan were disgraced. ${ }^{320}$ (Unfortunately, the public of the MTV era did not catapult Shaw,

315 Wikipedia: Milli Vanilli, http://en.wikipedia.org/wiki/Milli_Vanilli (last visited Aug. 12, 2005).

${ }^{316}$ Id. (describing Milli Vanilli as the only group ever to have a Grammy Award revoked).

${ }^{317}$ Id.

${ }^{318} \mathrm{Id}$.

319 A lawsuit was initiated based upon the claim that the public had been fraudulently deceived into purchasing Milli Vanilli albums by the misrepresentation that Morvan and Pilatus actually sang the vocals. See Freedman v. Arista Records, Inc., 137 F.R.D. 225 (E.D. Pa. 1991); Cross, supra note 20, at $709 \&$ n.1.

${ }^{320}$ Of course, Milli Vanilli was not the first band to be accused of inauthenticity. The 1960's pop band The Monkees, for instance, is commonly criticized for being deceptively inauthentic. The group was the brainchild of two entertainment executives, Bob Rafelson and Bert Schneider, who created the band as a way to use television to cash in on the Beatles phenomenon. They recruited the band members (two actors and two musicians) from auditions involving hundreds of aspirants. Stephen Stills of Crosby Stills \& Nash actually auditioned. A separate creative team wrote the Monkees' early songs and studio musicians were employed to play the musical instruments on the song tracks. At one point, it was even planned that the Monkees would simply lipsynch all their songs exactly as Milli Vanilli did, so that the band members would contribute nothing but their images and acting. Ultimately, however, some members of the band were allowed to add vocal tracks to the songs. While the band members were originally hired for $\$ 450$ a week and less than 2 percent of the record royalties, they followed the normal path of leveraging their acquired fame to push for greater creative control. Those efforts were partially successful - records and singles by the Monkees at times topped sales of the Beatles - but greater creative control also heralded the band's decline. The group's chemistry, its public image, and its fame were largely attributable to the success of the syndicated television show and the "authorship" of the two creative managers. The individual members had to struggle - largely unsuccessfully 
Davis, and Howe to stardom.) After a long downward career spiral - including a stint in prison - Rob Pilatus died of a drug overdose in Germany in 1998. ${ }^{321}$

The moral conclusions of both Singin' in the Rain and the Milli Vanilli affair might seem congruent. However, looking past the fiction of Singin' in the Rain, the making of the movie tells a completely different story. Kathy Selden actually had her own Kathy Seldens: Betty Noyes sang many of Debbie Reynolds's songs in the film and Gene Kelly actually dubbed some of Reynolds's tap dancing. ${ }^{322}$ In the most interesting reversal - Jean Hagan (who played Lamont) dubbed Reynolds's speech in the scenes where Selden was dubbing the voice of Lamont. ${ }^{323}$ Even in 1952, in a film marketed to the public as a story about the triumph of artistic authenticity, the makers of the film had very little interest in authenticity. ${ }^{324}$ Hollywood filmmakers still dub vocal performances just as readily as they use stunt and body doubles to attribute greater prowess and beauty to the celebrities. ${ }^{325}$ Marni Nixon is probably the most famous Kathy Selden figure in Hollywood. ${ }^{326}$ She dubbed Deborah Kerr in the film version of The King and I, sang for Natalie Wood in West Side Story, and was Audrey Hepburn's voice in My Fair Lady. 327 Of course, few people know of her existence, and some undoubtedly think that Kerr, Wood, and Hepburn have remarkable singing voices.

My proposal would make the Milli Vanilli facts amenable to legal regulation, since the attributions of authorship to Pilatus and Morvan were used to promote and sell the work and were factually deceptive as to authorship. ${ }^{328}$ The misattributions that are inherent in the public's reading of

- to become something like the musical group that they played on television. For extended versions of this story, see ERIC LefCOWITZ, The MonkeEs' TALE (2d ed. 1989); Mickey Dolenz \& Mark Bego, I'M a Believer: My life of Monkees, Music, And Madness (2004). If you actually want to follow up on this footnote, I would recommend the Lefcowitz book. It's much easier to read.

321 See VH1: Milli Vanilli, http://www.vh1.com/artists/az/milli_vanilli/bio.jhtml (last visited Aug. 12, 2005).

322 Steven Cohan, Case Study: Interpreting Singin' in the Rain, in REINVENTING FILM STUDIEs 59 (Christine Gledhill \& Linda Williams eds., 2000).

${ }^{323}$ Id.

324 Perhaps this is why Hollywood loves Singin' in the Rain so much - there's plenty of irony if you know the inside story.

325 In the film, Don Lockwood breaks into the film industry by performing as another actor's stunt double.

326 Douglas R. Hofstadter, Le Ton Beau De Marot: In Praise of the Music of LANGUAGE 62 (1998) (recounting Nixon's career as a "ghost” singer for several famous actresses).

${ }^{327}$ Id.; see also Wikipedia: Marni Nixon, http://en.wikipedia.org/wiki/Marni_Nixon (last visited Sept. 15, 2005).

328 An interesting twist on the Milli Vanilli affair occurred recently. A 1980s-era band of aging punk rockers, The Alarm, drafted members of a much younger band to appear on screen, while the music of The Alarm was dubbed on top of the visuals. Apparently, this 
Singin' in the Rain, however, should not be actionable because they are not made extrinsic to the work. Obviously, this is somewhat problematic. The dubbing in Singin' in the Rain creates the potential for public deception with regard to the singing talents of actors. The visually presented actor who is dubbed (i.e., Debbie Reynolds) almost certainly garnered a public reputational value that should have been properly attributed to an undisclosed collaborator (i.e., Betty Noyes). And just as in ghostwriting, this worked well from a marketing perspective - both Noyes and Reynolds benefited.

But the vocal dubbing deception in Singin' in the Rain isn't linked to the sale of the work or severable from the work. Perhaps more importantly, there would have been no way to correct the deception within the context of collaboratively produced work without disrupting the integrity of the movie. It would also seem unwise, and perhaps impossible, to attempt to "fix" the public confusion as to authorship in Singin' in the Rain without destroying the film or, in any event, providing the public with far more information than it would want or need in order to make purchasing decisions. And if we "fix" the misattribution in Singin' in the Rain, why stop there? We could require disclaimers for all potentially deceptive practices in film, e.g., special effects, body doubles, stuntmen, and digital editing. But accepting that the entertainment industry is premised on the creation and sale of illusions, there are sound reasons to be conservative in attempting to root out instances of consumer deception.

\section{The Inherent Deceptions of Art}

This last point - that the marketing of illusion is inherently deceptive - is worth a few additional comments. The goal of trademark law, in a very broad sense, is to promote truth in market communications. Yet art, as Picasso noted, is a lie. ${ }^{329}$ Obviously there is some potential here for conflict. To illustrate the kind of misattribution that is inherent in the artistic form, we might look to Edmond Rostand's Cyrano de Bergerac. The play is essentially a story of authorial misattribution. ${ }^{330}$ The interesting tension latent in the play is that the

approach worked and the song gained a considerable amount of airplay. The band then raised the curtain on itself and explained that it had engaged in the duplicity because: "We wanted to make sure we are judged purely on the strength of the music, and not by our old hairstyles." See BBC Wales: The Alarm, http://www.bbc.co.uk/wales/music/profiles/pages/alarm.shtml (last visited Aug. 12, 2005) (describing The Alarm as one of the most internationally successful rock bands to come out of Wales).

${ }^{329}$ A lie that tells the truth, but a lie nonetheless.

330 Edmond Rostand, Cyrano De Bergerac (Brian Hooker trans., Bantam Classics 1950). In brief summary, Cyrano, who has a rather large and aesthetically unappealing proboscis, writes words for another suitor, Christian, to deliver to the lovely Roxane, who is also the object of Cyrano's affections. At the end of the play, after the passage of many years, the misattribution of Cyrano's words to Christian's authorship is revealed, and Roxane declares her love for Cyrano, the author. Cyrano dies of injuries moments later. 
artifice of authorial misattribution that is condemned in the play is, in fact, integral to the dramatic form of the play itself. When watching the play, we suspend our disbelief in the identity of the actor and attribute the words of Rostand to the authority of the actor who plays Cyrano. Within and without the context of the performance, we are told that authorial misattribution runs the risk of fraud. Yet within the play, misattribution is inherent in the collaboration between playwright and actor in creating the fictional world.

Given our tendency to confuse the image with reality and the dancer with the dance, policing the line between fraud and entertainment can become problematic. Can we cleanly separate our beliefs about popular actors, for instance, from the roles that they play? When we see films, we suspend our disbelief of not only the spontaneity of the actor's performance, but also of the entire artifice of the play's constructed world. To some extent, after the film is over, we can mentally sever the identity of the actor from the special effects, the effects of editing, the contribution of collaborators, and all the other material we see on the screen. To some extent, though, we cannot. Arnold Schwarzenegger's recent success in the California gubernatorial election suggests the extent to which Hollywood can construct identity. Schwarzenegger's popular appeal was surely based, in substantial part, on his association with stern, indestructible cyborgs, barbarians, and maverick action heroes. ${ }^{331}$ To some extent this was deceptive. His performances were the result of scripted fictions, and scripted fictions are inherently deceptive in at least two ways. First, the identity of the actor is merged with the identity of the fictional character. Second, the performer often reaps credit for the work of numerous other collaborative players: writers, composers, choreographers, and other contributors who are not obvious to those viewing the performance.

However, there are limits to what we can do with attempts to bring laws requiring truthful communication to the commercial enterprise of art. I would suggest that while the regulation of extrinsic authorial designations that are relevant to consumers will not generally intrude on art's deceptive nature, attempts to move past that point would be going too far. If we attempt to move beyond the truth of extrinsic designations and regulate the ways in which art intrinsically deceives and confuses the public, we run the risk of curtailing the illusions and deceptions that are inherent in art.

\section{CONCLUSION}

This article has suggested that there are good reasons to reverse the holding of Dastar through legislation and to reintroduce the role of trademark law into the regulation of designations of authorship, at least to some conservative extent. When we do this, however, we are also making a decision about the

${ }^{331}$ See Actor Biography: Arnold Schwarzenegger, The Internet Movie Database, http://www.imdb.com/name/nm0000216 (last visited Aug. 12, 2005). 
type of authorship that society obtains from the intellectual property system. ${ }^{332}$ The decision between trademark law and proprietary-based schemes is also a question of cultural aesthetics. As noted before with regard to the lip-synching practice of Milli Vanilli, misattributive practices can lead to the creation of very marketable illusions. ${ }^{33}$ To the extent trademark law requires honesty in attribution, it may make those illusions less likely to occur. Does our society profit from marketable illusions such as deathless and impossibly prolific authors, photogenic singers with angelic voices, and Hollywood-forged mythic political candidates? If people are willing to buy this stuff, isn't that how we should weigh social utility?

Perhaps society would actually be better off if Jeff Rovin and Andrew Neiderman were forced to publish novels under their own names, if not all our singers were photogenic, and if our system of politics was not so dependent on speechwriters and the business of illusion. Would the unknown authors Rovin and Neiderman be better off if trademark law cast a shadow on their respective enterprises? Probably not, but for every penny spent on a book written by a Neiderman or a Rovin, there are surely many other authors who are attempting to capture the public attention, retracing the steps of the fictional Kathy Selden in Singin' in the Rain, believing that there is some truth to the story of her success. This competition among artists and authors for our limited attention is a zero-sum game. The shelf space devoted to the latest V.C. Andrews ${ }^{\mathrm{TM}}$ (Neiderman) and Tom Clancy ${ }^{\mathrm{TM}}$ (Rovin) books in my library is shelf space that cannot be used by the lesser-known authors who actually write under their own names.

The law can provide no complete panacea for the business practices and marketing concerns that misallocate authorship. Even if trademark law can come to the rescue to some limited degree, the costs and mechanics of enforcement and the inherent difficulties in ascertaining the facts of authorship might mean that ghostwriting and other misattributive practices would continue largely unchecked. But it is justifiable to cast misattributive practices under a legal shadow. Trademark law should not countenance intentional and misleading public deception where it can serve as a remedy. Nor should our intellectual property laws simply concentrate on the goal of production, pumping out greater and greater quantities of expressive material for people to "consume." We should take account of the greater interests of society and the goals of all of this productive activity.

As was demonstrated with the example of Michelangelo in Part I, the artistic pursuit of quality, fueled by the desire to make a name for oneself and achieve personal goals, is sometimes at odds with the pursuit of quantity.334 Trademark has a role to play in promoting quality by forcing each individual

\footnotetext{
332 See supra Part III.

333 See Wikipedia: Milli Vanilli, supra note 315.

334 VASARI, supra note 33, at 472 (describing how Michelangelo destroyed many of his own works that did not meet his standards).
} 
author to stand on his or her own two feet and by discouraging practices where one author claims undue credit for the authorship of others. The goals of trademark align with social intuitions condemning plagiarism and popular conceptions of what intellectual property law is designed to do. ${ }^{335}$ By restoring the trademark function of authorship and prohibiting deceptive misattributions of authorship that result in consumer harms, we might embrace what appears to be an increasingly radical concept in intellectual property law. Trademark and copyright are not simply laws intended to parcel out new private property rights - they are laws that should be designed to promote and protect the greater interests of society.

335 See Anonymous, supra note 65 (illustrating the moral condemnation of plagiarism). 